\title{
Journal of Apicultural Research \\ Determination of Physico-biochemical Proprieties and Composition in Volatile Constituents by Solid Phase Micro-Extraction of Honey Samples from Different Botanical and Geographical Origins in Morocco --Manuscript Draft--
}

\begin{tabular}{|c|c|}
\hline Full Title: & $\begin{array}{l}\text { Determination of Physico-biochemical Proprieties and Composition in Volatile } \\
\text { Constituents by Solid Phase Micro-Extraction of Honey Samples from Different } \\
\text { Botanical and Geographical Origins in Morocco }\end{array}$ \\
\hline Manuscript Number: & TJAR-2018-0201R1 \\
\hline Article Type: & Original research article \\
\hline Keywords: & Morocco, Honey, Botanical Origin, Volatile compounds, SPME-GC-MS \\
\hline Manuscript Classifications: & Biochemistry and chemical ecology; Hive product science \\
\hline Abstract: & 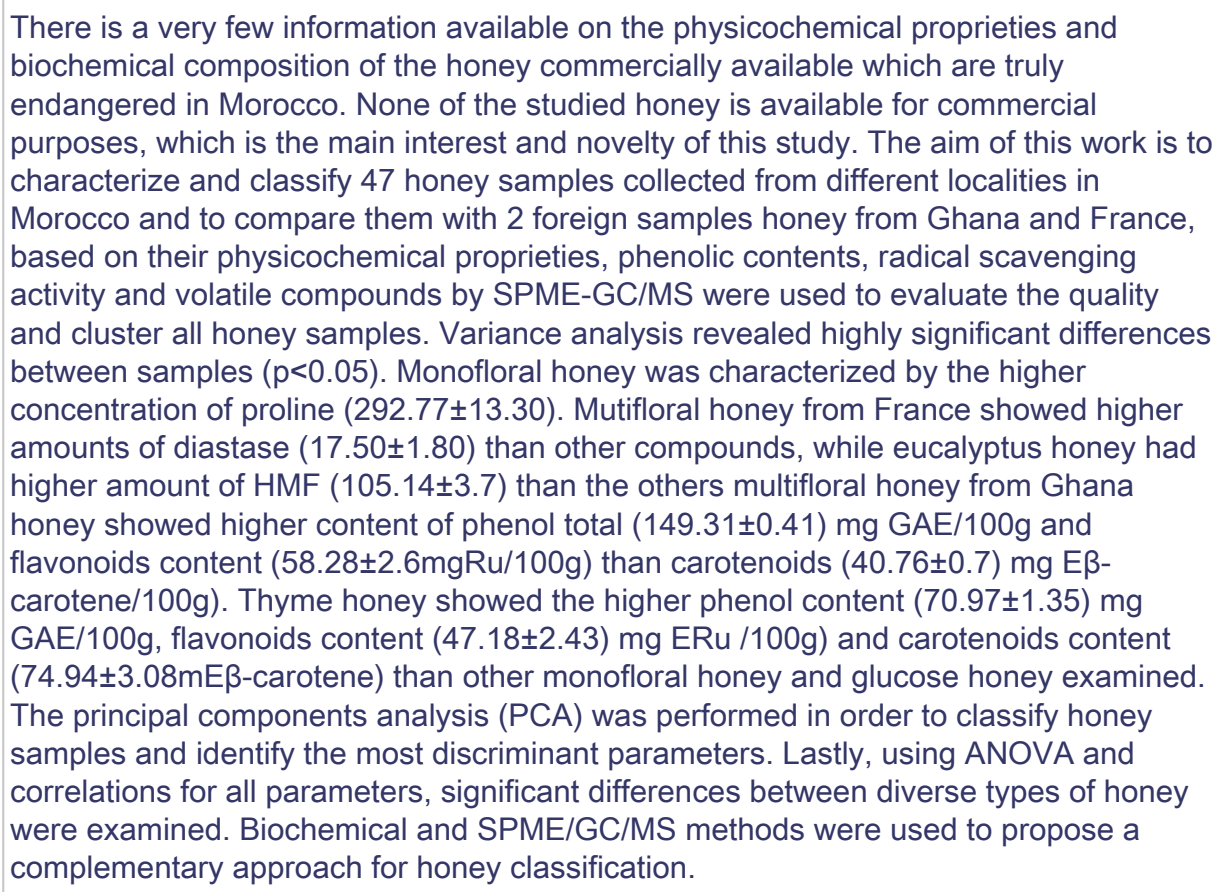 \\
\hline \multirow[t]{7}{*}{ Order of Authors: } & hanine hafida, PH D \\
\hline & Fauconnier Marie Laure, $\mathrm{Pr}$ \\
\hline & Kenne tierry, DR \\
\hline & Rizki hajar, Dr \\
\hline & Ouradi hamza, Dr \\
\hline & Ennahli said, Pr \\
\hline & Hssaini Lahcen, Dr \\
\hline Response to Reviewers: & $\begin{array}{l}\text { The article investigates the quality of } 47 \text { Moroccan honey collected from different } \\
\text { regions and botanical origin compared with } 2 \text { foreign samples from Ghana and France } \\
\text { (with a different botanical origins) based on several parameters of interest. Very } \\
\text { important findings have been revealed in this paper. Results showed the importance of } \\
\text { coupling SPME-GC/MS analysis with physico-biochemical assessment in order to } \\
\text { determine the honey sample quality. Statistical approach was of great interest in order } \\
\text { to discriminate samples and to cluster them based on their geographical and floral } \\
\text { origins. PCA analysis, revealed some aspects of resemblances in samples clustering } \\
\text { based on botanical and geographical origins. It also confirmed the importance to } \\
\text { conjugate physico-biochemical and volatile compounds analysis. These finding, are of } \\
\text { great importance, particularly in the Moroccan context. The paper provides some }\end{array}$ \\
\hline
\end{tabular}


interesting results either to the scientist and consumers about the honey quality that constitutes a major natural source of bioactive compounds in the health-promoting Morrocan diet for millennia.

The paper has been revised in the light of reviewer comments. Several changes were made and all remarks were considered while revising the manuscript. The main revisions are summarized in the tables below.

List of changes (classified in several items) according to the first reviewer comments

Item : free radical scavenging

Line numberOld statementNew statementComment

137All honey samples were collected from market. Honey samples were kept at $4-5^{\circ} \mathrm{C}$ until analysisAll honey samples were collected from market and local produced at different region. All samples were packed in glass bottles ( $100 \mathrm{~g} /$ honey/type) and stored in dark room at $4-5^{\circ} \mathrm{C}$ until analysisThe conditions of sampling are specified and completed

159

Proline content is determined calorimetrically according to (Von der Ohe et al., 1991) method. Proline was calculated following formulaProline content was determined calorimetrically according to (Von der Ohe et al., 1991) and calculated following formula:there are errors in the writing and in the grammar.

1972.3.4. DPPH radical scavenging assay2.3.4. DPPH free radical scavenging activityThe titled has been changed following the reviewer comment. Free radical scavenging are used instead of antioxidant activity, since the latter is a broad term of which free radical scavenging activity using DP

$\mathrm{PH}$ is one of several methods used to evaluate this aspect

308-210-The results are also expressed as using a mg of Trolox equivalent per $100 \mathrm{~g}$ of extract following formula The equation used to convert \% inhibition to trolox equivalent per extract (cited in the table 4, was added

453-454Freeradical-scavenging activities

of the different honey from different botanical origin

Free radical-scavenging activities using DPPH method (mg trolox equivalent/ $100 \mathrm{~g}$ of exract) of the different honey from different botanical originln the same context as above, the title of Table 4 was changed to be more explicit in the light of the first reviewer comments.

248Free antioxidant activity ( $\mathrm{mg} \mathrm{ET} / 100 \mathrm{gFree}$ radical scavenging activity ( $\mathrm{mg}$ Trolox eq. $/ 100 \mathrm{~g}$ )Same comments above (Table 2)

Item : Statistical analysis (use of the mean square and ${ }^{* * *}$ )

Line numberOld statementNew statementComment

245Duncan testpost hoc Duncan multiple-rangeFor more explicitness

248Descriptive analysis and analysis of variance of evaluated samplesDescriptive analysis and analysis of variance (mean squares) of evaluated samplesthe expression "(mean squares)" was added in order to make a reference to the fact that the table presents the ANOVA results as a mean squares followed with asterisks to mention the level of significant of the test

$248^{* * *}$ are presented over the mean square and denotes significant of difference at level of 0.001 according to analysis of variance. This expression was added in the foot of the table 2. In fact, ANOVA results are usually presented as $F$ and $P$ value or as a mean square with asterisks that refer to the level of significance of the test (ANOVA one way as is the case of this work)

Line numberOld statementNew statementComment

252-253 -The post hoc Duncan multiple-range test showed significant pairwise differences and classify simples into 21 homogenous subsetsThese statements were added following the comments of the first reviewer. They aims to mention the numbers of subsets as results of Duncan test (ANOVA)

330-331-The post hoc Duncan test classified simples into 20 homogenous subsets which attest an important significant pairwise differences

342-343Samples were classified into 20 subsets according to Duncan test $(p<0.05)$.

$335-337$ showed a high significant variability among samples $(p<0.001)$. Duncan multiple-range test showed significant pairwise differences with 21 homogenous subsets (table 2). Values

Item : table $2 \mathrm{~b}$ (delete in an earlier version) 
Line numberOld statementNew statementComment

340The color of honey samples are shown in table $2 \mathrm{~b}$. Results of honey samples color evaluation are given in the table 2The table 2b. doesn't exist (It was an oversight). In an earlier revision the table $2 \mathrm{~b}$ (honey sample color and international standards) and table 2a (descriptive analysis and ANOVA) were combined for a better synthesis an understanding

343The expression table $2 \mathrm{~b}$ was deleted.

Item : Principal component PCA (PCA)

Line numberOld statementNew statementComment

515Principal components Principal components (PC)"(PC)" was added in the table to explain the use of this abbreviation which means "principal component" PC1 and PC2principal components ...PC1 and PC2first and the second principal components PC1 and PC2....

tem : other changes

Line numberOld statementNew statementcomment

340 Data are the mean of three replicationsAverage values \pm standard errors of mean of three replicationsSample change for a better understanding.

451

3.6

Around 30 major volatile compounds were identified and semi quantified in the volatile fractions of honey samples

3.6. Volatile compounds characterization

HS-SPME method combined to GC-MS analysis allowed identification of about 30 compounds in honey samples which relative amounts are determinated based on percentage area. Identified compounds include alcohols, aldehydes, ketones, acids, esters, terpenes and nitrogen compounds are shown in Table 5

New table 5

Complete quantification of VOCs using HS-SPME in complex mixture as honey was nearly impossible even if the technique is very sensitive and practical than others. Indeed, it is very difficult to get the recovery rate of any individual compound using the SPME-fiber. Secondary, as a complex mixture of VOCs, each compound of honey compete against each other during the sampling step. In result some 'weaker' VOCs "lower affinity in term of polarity" are discriminated by 'stronger' ones. Additionally this discrimination depends on the amounts of each component in honey. In result, we can only get a 'semi-quantification' with HS-SPME method in this matrix sample. An internal standard will not help because you also do not know the recovery rate of the standard compound. So, the results are denominated "semi-quantification" because the recovery of each individual compound is not achieved and values are obtained based on percentage of area.

Regarding Olfacto-gustatory profile, this part does not address the question, that why we have cancelled. 
It seems to be a typing error and values in table have been displaced we would like to write Table 5

\section{Response:}

It seems to be a typing error and values in table have been displaced.

We would like to write: Table 5

Type of honeyCompoundCAS numberPercentage \%

Caralluma europaeaEthanol64-17-539.2

lilac aldehyde A53447-45-3 8.6

lilac aldehyde D3447-48-6 6.6

nonanoic acid112-05-08.7

benzoic acid,65-85-0

2.0

Eucalyptus sppethanol64-17-518.5

lilac aldehyde C78-59-114.5

benzeneacetaldehyde122-78-16.3

benzeneethanol60-12-85.7

nonanoic acid112-05-011.0

ethanol64-17-538.5

Thymus spp8-hydroxylinalool103619-06-33.9

ethyl nonanoate123-29-510.4

lilac aldehyde C53447-47-56.1

benzeneacetic acid103-82-22.4

ethanol64-17-520.4

Citrus $x$ sinensisfurfural98-01-16.3

benzeneethanol60-12-814.5

nonanoic acid112-05-010.4

2,5-furandicarbaldehyde823-82-52.2

ethanol64-17-512.7

Ceratonia siliquafurfural98-01-114.4

2,3-butanediol513-85-94.5

nonanoic acid112-05-010.5

octanoic acid124-07-27.7

ethanol64-17-513.3

Ziziphus lotusacetic acid64-19-79.5

(z)-linalool oxide5989-33-36.3

furfural98-01-18.1

pentanoic acid109-52-413.2

ethanol64-17-511.1

Euphorbiafurfural98-01-18.9

Isoborneol10385-78-19.4

2,5-furandicarbaldehyde823-82-514.4

anisaldehyde50984-52-67.5

beta myrcene123-35-314.1

Multifloral honey Moroccodl-limonene138-86-36.4

(z)-linalool oxide5989-33-313.4

sorbic acid22500-92-116.3

pentanoic acid109-52-44.5 
Running head: Biochemical and volatile honey profile

Determination of Physico-biochemical Proprieties and Composition in Volatile Constituents by Solid Phase Micro-Extraction of Honey Samples from Different Botanical and Geographical Origins in Morocco

Hanine $\mathrm{H}^{\mathrm{a}^{*}}$, Fauconnier $\mathrm{ML}^{\mathrm{b}}$,Kenne $\mathrm{T}^{\mathrm{b}}$, Rizki $\mathrm{H}^{\mathrm{a}}$, Ouradi $\mathrm{H}^{\mathrm{a}}$,EnnahliS ${ }^{\mathrm{c}}$, HssainiL ${ }^{\mathrm{a}, \mathrm{d}}$

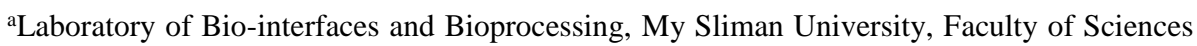
and Technics, BO 523 BeniMellal, Morocco

baboratory of Volatolomic, Gembloux AgroBiotech, University of Liege, Passage des Déportés, 25030 Gembloux, Belgium

${ }^{\mathrm{c}}$ National School of Agriculture, ENA, Meknes, Morocco

${ }^{\mathrm{d}}$ National Institute of Agricultural Research (INRA), Meknes, Morocco

*Corresponding author: hafidahanine0@gmail.com

The authors are grateful to the Agricultural Cooperative of Afourer (Morocco) for providing samples and support in this collecting necessary information about local honey. The technical support of the faculty of Gembloux Agro Biotech of LiegeUniversity (Belgium) for technical support. 
Running head: Biochemical and volatile honey profile Abstract
There is a very few information available on the physicochemical proprieties and
biochemical composition of the honey commercially available which are truly endangered in
Morocco. None of the studied honey is available for commercial purposes, which is the main
interest and novelty of this study. The aim of this work is to characterize and classify 47
honey samples collected from different localities in Morocco and to compare them with 2
foreign samples honey from Ghana and France, based on their physicochemical proprieties, phenolic contents, radical scavenging activity and volatile compounds by SPME-GC/MS were $\underline{\text { used to evaluate the quality and cluster all honey samples. Variance analysis revealed highly }}$ significant differences between samples $(\mathrm{p}<0.05)$. Monofloral honey was characterized by the higher concentration of proline $(292.77 \pm 13.30)$. Mutifloral honey from France showed higher amounts of diastase $(17.50 \pm 1.80)$ than other compounds, while eucalyptus honey had higher amount of HMF $(105.14 \pm 3.7)$ than the others multifloral honey from Ghana honey showed higher content of phenol total $(149.31 \pm 0.41) \mathrm{mg}$ GAE/100g and flavonoids content $(58.28 \pm 2.6 \mathrm{mgRu} / 100 \mathrm{~g})$ than carotenoids $(40.76 \pm 0.7) \mathrm{mg} \mathrm{E} \beta$-carotene $/ 100 \mathrm{~g})$. Thyme honey showed the higher phenol content $(70.97 \pm 1.35) \mathrm{mg}$ GAE$/ 100 \mathrm{~g}$, flavonoids content $\underline{(47.18 \pm 2.43) \mathrm{mg} \mathrm{ERu} / 100 \mathrm{~g}) \text { and carotenoids content }(74.94 \pm 3.08 \mathrm{mE} \beta \text {-carotene) than other }}$ monofloral honey and glucose honey examined. The principal components analysis (PCA) was performed in order to classify honey samples and identify the most discriminant parameters. Lastly, using ANOVA and correlations for all parameters, significant differences between diverse types of honey were examined. Biochemical and SPME/GC/MS methods were used to propose a complementary approach for honey classification.

There is a very few information available on the physicochemical proprieties and biochemical eomposition of the honey commercially available which are truly endangered in Moroces. None of the studied honey is available for commercial purposes, which is the main interest 
Running head: Biochemical and volatile honey profile

and novelty of this study. The aim of this work is to characterize and classify 47 honey samples collected from different localities in Moroceo and to compare them with 2 foreign samples honey from Ghana and France, based on their physicochemical proprieties, phenolic contents, radieal seavenging activity and volatile compounds. Spectrophotometric methods and solid phase micro extraction SPME GC/MS were used to evaluate the quality and cluster all collected honey samples. Variance analysis revealed highly significant differences between samples ( $\mathrm{p}<0.05)$. Monofloral honey was characterized by the higher concentration of proline $(292.77 \pm 13.30)$. Mutifloral honey from France showed higher amounts of diastase $(17.50 \pm 1.80)$ than other compounds, while eucalyptus honey had higher amount of HMF $(105.14 \pm 3.7)$ than the others multifloral honey from Ghana honey showed higher content of phenol total $(149.31 \pm 0.41) \mathrm{mg}$ GAE/100g and flavonoids content $(58.28 \pm 2.6 \mathrm{mgRu} / 100 \mathrm{~g})$ than carotenoids $(40.76 \pm 0.7) \mathrm{mg} E \beta$-carotene/100g). Thyme honey showed the higher amount

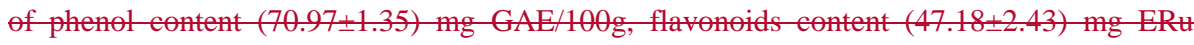
$400 \mathrm{~g})$ and carotenoids content $(74.94 \pm 3.08 \mathrm{mE} \beta$ carotene) than other monofloral honey and glucose honey examined. The principal components analysis (PCA) was performed in order to classify honey samples and identify the most discriminant parameters. Lastly, using ANOVA and correlations for all parameters, significant differences between diverse types of honey were examined. Biochemical and SPME/GC/MS methods were used to propose a eomplementary approach for honey classification.

Keywords:Morocco,Honey, Botanical Origin, Volatile compounds, SPME-GC-MS

\section{Introduction}

Honey is the natural sweet substance produced by honeybees from the nectar of blossoms or from the secretion of living parts of plants or excretions of plant sucking insects on the living parts of plants. For the formation of honey, honeybees collect, transform and 
Running head: Biochemical and volatile honey profile

combine the secretion of plants or the nectar of blossoms with specific substances of their own, store and leave in the honey comb to ripen and mature (Codex alimentarus, 2001). Consisting of a complex mixture of carbohydrates (80-85\%) (White etDoner, 1980), most important sugars existed in honey are fructose and glucose. Also, honey contains water, 0.1$0.4 \%$ protein, $0.2 \%$ ash and minor quantities of amino acids, enzymes and vitamins (White etDoner, 1980; Jeffrey and Echazarreta, 1996; Gheldof, etal., 2002; James, 2009). A wide range of minor constituents is also present in honey, which many of them are known to have antioxidant properties. These minor constituents include phenolic acids and flavonoids (Martos et al., 2000), the phenolic compounds of honey are collected first by the bees from the plants. The total phenolic content in honey is strongly correlated with its antioxidant activity (Beretta et al., 2005; Bertoncelj et al., 2007; Meda et al., 2005). Honey is considered to be one of the nature's original sweetener, it has been used as a food for at least six thousand (Grahan, 1992). It was reported that honey is rich with two classes of phenolic acid: substituted benzoic acids and cinnamic acids, and flavonoids. Those compounds could be considered as potential markers for the botanical origin of honey (Alvarez-Suarez et al., 2012). Flavonoids reported in honey are flavonols, flavonones and flavones, they contribute on the pigmentation, taste and flavor of honey (Estevinho et al., 2008). These minor constituents are known to have distinctive nutritional or medicinal properties (James etal., 2009). However, the specific composition depends on many factors, such as the nectar composition of the plant source, bee species, the climate, environmental and seasonal conditions, agricultural practices and treatment of honey during extraction and storage (Marchinietal., 2006; Iglesias and al., 2012).

Honey is one of the most targeted commercial product for nutritional, medicinal and industrial purposes. The chemical and physical properties of honey influence positively honey healing capacity, with a great role in the treatment of burns, gastrointestinal disorders, 
Running head: Biochemical and volatile honey profile

respiratory illnesses, infected and chronic wounds (Castaldo\&Capasso, 2002; Orhan et al., 2003; Ramalhosa et al., 2011). The antibiotic properties of honey have been scientifically proven (MolanetBetts, 2004). The antimicrobial effectiveness reported have been evaluated with diverse setsof methodologies, degrees of sensitivity and microbial strains, what leads to difficulties comparing results from work teams (Vargas et al., 2007).

Aroma compounds are also present in honey at very low concentrations as complex mixtures of volatile components different in their chemical structure and, with a relatively low molecular weight. Regarding the composition of volatiles, authors report that same volatile components are present in the majority of honey, although the mutual proportions of these substances can be different (Verzera et al. 2001; De la Fuente et al. 2005; Radovic et al. 2001; Soria et al. 2002, 2004; Thrasyvoulou et al. 2002; Anklam 1998; Piasenzotto et al. 2003; Overton, Manura 1999). Similarly, some components are specific to only one type of honey. So, the composition of volatile compounds of honey could be used as biomarkers to determine its botanic origin. The composition and properties of a particular honey sample depend highly on the type of flowers visited by the bees as well as on climatic change. Honeybees and their products can also be employed as potential bioindicators of environmental contamination. These specific chemical and physical properties could be used for the determination of the botanical origin of honey (Marcelo E C et al, 2007)

Each type of honey with different origin has been affirmed with the occurrence of at least 113 volatile compounds belonging to the following classes of compounds: acyclic and monocyclic monoterpens and their oxygenated derivatives, furan and sulfuric derivatives, aliphatic, aromatic and nitrogenous compounds. Even if the large number of these compounds were reported in previous studies, only some of them could be considered as potential markers of the botanical origin of a given type of honey. 
Running head: Biochemical and volatile honey profile

For quality control of honey, several physical and chemical features, which mostly include water content, enzyme activity of invertase, hydroxymethylfurfural (HMF), electrical conductivity, and sugar composition, have to be determined but very few studies have analyzed physical and chemical properties of some honey, but none of them have determined the biochemical parameters of the different varieties of honey in Morocco. So, the aim of the current study was to evaluate the biochemical composition and the antioxidant activity of different types of honey, and also to identify the volatile composition honey using SPME-GCMS techniques to eventually identify the biomarkers of each variety of honey. The goal of the present work was first, to verify some of the qualitative parameters such proline, HMF, diastase, and second, to contribute to the very scarce available data on volatiles compounds content of Morocco region honey. Furthermore, we have evaluated if the physicochemical, biochemical parameters and volatiles compounds content of Morocco honey can determine the botanical origin. The sampling protocol was made up in order to obtain the most representative insight of the sampled regional areas. All samples were collected in Morocco regions.

In the present work, 47 samples of honey within a defined area of Morocco were collected and two multifloralhoney samples from Ghana and France. The influence of botanical origin and technical practice on (i) biochemical composition and volatile organic compounds, (ii) the nutritional and elemental composition of honey wasanalyzed. We used methods of multivariate analysis, such as cluster and discriminants analysis, and attempted to track differences (if any), both between individual samples of honey. 
Running head: Biochemical and volatile honey profile

\section{Materials and methods}

150

\section{Honey Samples}

The study was conducted on 47 samples of the typical honey produced in Different locality of Morocco. The honey samples came from various botanical origins; They include seven unifloral and multifloralhoney( Table.1): Carallumaeuropaea honey, Eucalyptus spp honey, Thymespp honey, Citrus x sinensis honey ), Ceratoniasiliqua honey, Ziziphus lotus honey , Euphorbia honey, multifloralhoney samples,multifloral_foreign honeysamples (GTffrom Ghana and , FTF ( honey from France)) and syrups sugar honey (SY). All honey samples were collected from market and local produced at different region. All samples were packed in glass bottles $\left(100 \mathrm{~g} /\right.$ honey/type), and stored in dark room at $4-5^{\circ} \mathrm{C}$ until analysis: Honey samples were kept at $45^{\circ} \mathrm{C}$ until analysis. All tests were performed in triplicate.

Table.1.

Botanical and geographical origins of studied honeysamples

\begin{tabular}{|c|c|c|c|}
\hline \multicolumn{2}{|c|}{ Honey type } & \multirow{2}{*}{$\begin{array}{l}\text { Locality } \\
\text {-Morocco }\end{array}$} & \multirow[b]{2}{*}{ - Tiznit } \\
\hline Carallumaeuropaea & $-\operatorname{TzDg} 1,2,3$ & & \\
\hline \multirow[t]{2}{*}{ Eucalyptusspp } & - Jdeuc1,2,3 & - Morocco & - El Jadida \\
\hline & - Ceuc1,2,3 & - Morocco & -Casablanca \\
\hline \multirow[t]{2}{*}{ Thymusspp } & - TiTh1,2,3 & - Morocco & -Azilal \\
\hline & - AssTh1,2,33 & - Morocco & - Tinghir \\
\hline \multirow[t]{2}{*}{ Citrus $x$ sinensis } & - BaOr1,2,3 & - Morocco & - BeniMellal \\
\hline & - ByOr1,2,3 & - Morocco & - BeniMellal \\
\hline \multirow[t]{4}{*}{ Ceratoniasiliqua } & $-\mathrm{KbCa} 1,2,3$ & - Morocco & - Khenifra \\
\hline & - ZeCa1,2,3 & - Morocco & Poni Molloy \\
\hline & - AdCa1,2,3 & - Morocco & - Beni Mellal \\
\hline & & & - Beni Mellal \\
\hline Ziziphus lotus & - FbJu1,2,3 & - Morocco & - FkihBensalah \\
\hline \multirow[t]{4}{*}{ Euphorbia } & - BtEup1,2,3 & - Morocco & - Beni Mellal \\
\hline & - BzEup1,2,3 & - Morocco & 10 \\
\hline & - BkEup1,2,3 & - Morocco & - Azilal \\
\hline & & & - Beni Mellal \\
\hline \multirow[t]{4}{*}{ multifloralhoney } & -MTf & - Morocco & -FkihBensaleh \\
\hline & - FoTf, FeHe, ML & - Morocco & - FkihBensalah \\
\hline & - FTf, PE & -France & \\
\hline & - GTfMTf & -Ghana & \\
\hline
\end{tabular}

Formatted: Font color: Custom Color(RGB $(68,114,196))$

Formatted: Font color: Custom Color(RGB $(68,114,196))$ Formatted: Font color: Custom Color(RGB $(68,114,196))$

Formatted: Font color: Custom Color(RGB $(68,114,196))$ 
Running head: Biochemical and volatile honey profile

Syrups sugar honey - - Sy $\quad$ - Morocco

\subsection{Physicochemical analysis}

The HMF, diastase activity, and Proline were determined according to Association of Official Analytical Chemists (AOAC) methods.

\subsubsection{Hydroxy Methyl Furfural (HMF) content}

The HMF content measurement is based on the absorbance at $284 \mathrm{~nm}$ according to White method( White and Doner, 1980). HMF content ( $\mathrm{mg} / \mathrm{Kg}$ of honey) is calculated as follows :

$\mathrm{HMF}=(\mathrm{A} 284 \mathrm{~nm}-\mathrm{A} 336 \mathrm{~nm}) \times 149.7 \times 5 \times \mathrm{D}$.

Where A284 nm and A336 nm correspond to absorbance levels of sample solution at 284 and $336 \mathrm{~nm}$ respectively, the constant of 149.7 was derived from the molecular weight of HMF and the molar absorptivity of HMF at $\lambda=284 \mathrm{~nm}$ and finally $\mathrm{D}$ is the dilution factor.

\subsubsection{DiastasicIndex (Bogdanov et al, 1997).}

The diastase index(DI) was determined according to (Bogdanov and al, 1997) by monitoring the absorbance at 660 to reach 0.235 . A plot of absorbance against time, or a regression equation, was used to determine the time (tx) required to reach the specified absorbance, 0.235 . The Diastase Number (Schade unit) is calculated as 300 divided by tx

\subsubsection{Proline content}

Proline content is determined calorimetrically according to_(Von der Ohe et al., 1991)method.

Proline content was calculated by following formula:

Proline $(\mathrm{mg} / \mathrm{Kg})=(\mathrm{Ps} / \mathrm{A}) \times(\mathrm{P} / \mathrm{P} 2) \times 80$ 
Running head: Biochemical and volatile honey profile

7184 8

Where Ps is absorbance of the sample solution, A is the average of the two absorbances.

Measurements for the proline standard solution, $\mathrm{P}$ is the $\mathrm{mg}$ of proline taken for the stoke solution, $\mathrm{P} 2$ is the weight of honey in grams and 80 is the dilution factor.

\subsubsection{Honey color measurement}

The honey color was measured by a spectrophotometric measurement according to(White method 1980). Honey samples were heated to $45^{\circ} \mathrm{C}$ to dissolve sugar crystals; and the color was determined using by spectrophotometer using(Spectra physic, Jasco) of the absorbance of $50 \%$ Diluted honey solution $(\mathrm{w} / \mathrm{v})$ at $635 \mathrm{~nm}$. The honey was classified according to the Pfund scale after conversion of the absorbance values

$$
\mathrm{mm} \text { Pfund }=38.70-371.39 \times \text { Abs }
$$

Where the Pfund is the intensity of the honey color in the pfund scale and Abs is the absorbance at $635 \mathrm{~nm}$.

\subsection{Phytochemical analysis}

\subsubsection{Total phenolic content}

The total phenolic content (TPC) was determined with Folin-Ciocalteu reagent by absorbance measurement at $725 \mathrm{~nm}$ using gallic acid as standard as described by (Velioglu and al. 1998) with minor modification. Each $1 \mathrm{~g}$ of honey sample was diluted to $10 \mathrm{~mL}$ with distilled water. $0.5 \mathrm{~mL}$ of honey solution was then mixed with $3.7 \mathrm{~mL}$ of Folin-Ciocalteu reagents. After incubation for 5 minutes, $3.7 \mathrm{~mL}$ of $60 \% \mathrm{w} / \mathrm{v}$ aqueous sodium carbonate solution was added and the mixture was incubated at room temperature for 90 minutes. The absorbance of the reaction mixture was measured and total phenolic content was expressed in mg of gallic acid equivalent (GAE) per kg of honey.

\subsubsection{Total flavonoids content}

Total flavonoid content (TFC) was determined using rutin as the standard at 430nm according to (Djeridane et al 2006). A1 \% honey solution was prepared in warm water $(0.4 \mathrm{~g} / \mathrm{mL})$ and 
Running head: Biochemical and volatile honey profile

mixed with $1 \mathrm{~mL}$ of aluminum chloride (2\%) diluted with methanol. The results were expressed in mg rutin equivalent per100g of honey.

\subsubsection{Determination of carotenoids content}

The carotenoids extraction was carried out using the method of (Soto-Zamora et al 2005) where $0.1 \mathrm{~g}$ of honey was dissolved in $10 \mathrm{~mL}$ in a solvent mixture with different percentages (hexane: $50 \%$, ethanol: $25 \%$ and acetone $25 \%$ ), after the addition of $0.5 \mathrm{~mL}$ of $1 \mathrm{M} \mathrm{KOH}$ the mixture was stirred for 90 minutes and the absorbance was measured at $470 \mathrm{~nm}$. the results are expressed in $\mathrm{mg}$ of $\beta$-carotene equivalent / $\mathrm{g}$ of honey.

\subsubsection{DPPH free radical scavenging assayactivity}

The antioxidant activity of honey samples in the presence of the stable free radical DPPH was measured as described previously (Hartmann, 2007). Briefly, $1.25 \mathrm{~mL}$ of honey solution was dissolved in distilled water $(0.025 \mathrm{~g} / \mathrm{mL})$ and was mixed with $1.5 \mathrm{~mL}$ of a $60 \mathrm{mM}$ solution of DPPH in methanol. After $5 \mathrm{~min}$, the absorbance was read at $517 \mathrm{~nm}$ against water/methanol $(1: 1 \mathrm{v} / \mathrm{v})$ blank. For the control sample, $1.25 \mathrm{~mL}$ of methanol was mixed with $1.5 \mathrm{~mL}$ DPPH. After 30mn the remaining DPPH radicals were quantified by measuring the absorption at 517 $\mathrm{nm}$. The antioxidant activity of honey was expressed as a percentage of inhibition and was calculated using the following formula (Meda et al, 2005)

$\%$ inhibition $=[(\mathrm{A} 0-\mathrm{A} 1) / \mathrm{A} 0] * 100$, where $\mathrm{A} 0$ was the absorbance of the control solution and A1 was the absorbance in the presence of the sample and standards.

The results are also expressed as using a mg of Trolox equivalent per $100 \mathrm{~g}$ of extract following formula :

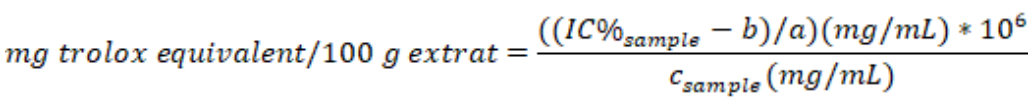

\subsection{Volatile compound analysis: Extraction and GC-MS analysis}


Running head: Biochemical and volatile honey profile

Static headspace extraction of volatile compounds was performed by using solid phase microextraction (SPME) with a $65 \mu \mathrm{m}$ Divinylbenzene / Carboxen / Polydimethylsiloxane (DVB/CAR/PDMS) fiber. The analysis of the honey components was carried out by gas chromatography-mass spectrometry (GC-MS) using a gas chromatography Agilent 7890A with masse selective detector 5975Network MSD and coupled to an automatic sampling system MPS (Gerstel), a polyethylenglycol capillary column VF-WAXms (30 m x 0.25 mm i.d. x $0.25 \mu \mathrm{m}$ film thickness) and a split/splitless injector, and the Library pal600k. About $1 \mathrm{~g}$ of the investigated sample was placed into a $20 \mathrm{ml}$ vial closed with a screw and heated to $60^{\circ} \mathrm{C}$ for 20 minutes and the fiber was then exposed to honey headspace. After $20 \mathrm{~min}$, the SPME fiber was automatically withdrawn from the vial and introduced into the GC injector. Working conditions were :splitless mode with injector temperature at $250^{\circ} \mathrm{C}$, the oven temperature program was $50^{\circ} \mathrm{C}$ for 4 minutes, rising at $5^{\circ} \mathrm{C} /$ minute to $230^{\circ} \mathrm{C}$ (held for 10 minutes) ; then rising at $10^{\circ} \mathrm{C} /$ minute to $250^{\circ} \mathrm{C}$; and finally, 3 minutes at $250^{\circ} \mathrm{C}$, a constant flow of $1 \mathrm{ml} /$ minute (helium) was set up. Mass spectra were recorded in EI mode at $70 \mathrm{eV}$, scanning the $35-395 \mathrm{~m} / \mathrm{z}$ range. The interface and source temperature were 230 and $250^{\circ} \mathrm{C}$, respectively

\subsection{Statistical analysis}

Since analysis have been performed using a different measure unit which make them having Formatted: Line spacing: Double unequal weights, data were standardized so that each variable has a mean of 0 and a standard deviation of 1 .

Data analysis was performed using SPSS v22. They were subjected to one-way ANOVA followed by Duncan Multiple Range Test (DMRT) for comparison of their means tested at 95\% confidence level. Correlation coefficients and their levels of significance were calculated using Pearson correlation. Principal component analysis was carried out using correlation 
Running head: Biochemical and volatile honey profile

matrix and Varimax rotation method. Principal Component Analysis was used in order to visualize the relative distribution of the honey samples according to their botanical origin. The traditional approach is to use the first few PCs in data analysis since they capture most of the variation in the original data set.

\section{Results and discussion}

\section{Descriptive analysis}

Results of characterization are summarized in Table 2. Important ranges of variation were recorded for all variables, that showed a highly significant differences $(p<0.0 \underline{015})$ among evaluated samples. According post hoc Duncan multiple-rangeto Duncan test, all variables generated a high number of homogeneous groups that varied from 14 to 24 .

\section{Table.2}

Descriptive analysis and analysis of variance (mean squares) of evaluated samples

$\begin{array}{ccccll}\text { Mini } \quad \text { Max } & \text { Mean } & \text { Mean } & \text { Mean } & \text { Homogeneo } & \text { internationa } \\ & \text { Std. } \\ \text { Deviatio } & \text { Square } & & \begin{array}{l}\text { us groups } \\ \text { number }\end{array} & 1 \text { standard } \\ & n & & & \text { limits } \\ \text { (codex } \\ \\ & & & & \\ & & & \\ & & & \\ & & & \end{array}$

\begin{tabular}{llllllll}
\hline $\mathrm{HMF}(\mathrm{mg} / \mathrm{kg})$ & 0.38 & 108.88 & 45.66 & 3.13 & $2052.32^{* * *}$ & 21 & Less than
\end{tabular}

$40 \mathrm{mg} / \mathrm{kg}$

$\begin{array}{llllllll}\text { Proline }(\mathrm{mg} / \mathrm{kg}) & 0.35 & 302.15 & 191.1 & 15.48 & 7096.74 * * * & 20 & \text { Less than }\end{array}$

$\begin{array}{llll}0 & 180 \mathrm{mg} / \mathrm{kg}\end{array}$

$\begin{array}{lrrrrrr}\text { Color }(\mathrm{mm} & 3.007 & 390.96 & 126.5 & 3.56 & 27780.32 * * & 20\end{array}$

Pfund)

$\begin{array}{lllllllr}\begin{array}{l}\text { Diastasic Index } \\ \text { (UnitySchade) }\end{array} & 0 & 20 & 3.49 & 0.55 & 23.9^{* * *} & 14 & \begin{array}{r}\text { Less than } 8 \\ \text { Unity }\end{array} \\ \end{array}$

$\begin{array}{lllllll}\text { Phenols (mg } & 0.58 & 150.35 & 50.31 & 2.93 & 1206.63^{* * *} & 23\end{array}$

$\mathrm{EAG} / 100 \mathrm{~g})$

\begin{tabular}{lllllll}
\hline Flavonoides & 0.03 & 84.06 & 28.63 & 3.33 & $624.69^{* * *}$ & 21
\end{tabular}
(mg ERu/100g)

$\begin{array}{lllllll}\text { Carotenoides } & 0 & 194.55 & 47.90 & 31.29 & 1956.97 * * * & 24\end{array}$

carotene/100 g) 
Running head: Biochemical and volatile honey profile

\begin{tabular}{lllllll}
\hline Free Antioxidant & 20.32 & 44.03 & 35.50 & 1.46 & $42.25^{* * *}$ & 15 \\
Activityradical & & & & & & \\
scavenging & & & & & & \\
activity (mg & & & & & & \\
Trolox Eq. & & & & & & \\
ET/100g) & & & & &
\end{tabular}

\section{*** are presented over the mean square and denotes significant of difference at level of 0.001 according to analysis of variance.}

HMF content varied from $0.38 \pm 0.4$ to $108.88 \pm 3.9 \mathrm{mg} / \mathrm{kg}$ with an average of $45.66 \pm 3.13$

(table.2). The post hoc Duncan multiple-range test showed significant pairwise

differencesand classify simples into 21 homogenous subsets. The highest value was obtained with eucalyptus spp honey samples, however the lowest contentwas recorded by a mutifloralhoney samples $(0.38 \pm 0.4 \mathrm{mg} / \mathrm{kg})($ FoHe 2$)$. Hydroxymethylfurfural (HMF) is naturally present in honey, it is derived from a fructose degradation in under acidic condition and the postharvest associated trace levels reported range between 1 to $3 \mathrm{mg} / \mathrm{kg}$ (Falicco et al 2004, Makhloufi et al, 2010).

The concentration of HMF is considered as an indicator of honey freshness (Corbella and Cozzolino, 2006), because its content increases as honey is heated or aged (Marceau et al, 1994, khalil et al, 2010). As a tool to evaluate honey quality, international standards (Codex Alimentarius Commission, 2001) have recommend a limit of $40 \mathrm{mg} / \mathrm{kg}$. There was $40.82 \%$ of measured samples with HMF concentration above the limit (40mg / kg), the sample ZeCa 3 (Ceratonia_siliqua honey), old honey samples but not heated, showed a diastatic activity greater than 8 schade_which is the minimum value required by the (codex alimentarius, 2001) commission. However, overheated samples showed a water content higher than $20 \%$ in water contentwhich means there are easily degradable, Meanwhile; Although, $60 \%$ of the samples had HMF contents below $40 \mathrm{mg} / \mathrm{kg}$, suggesting there were fresh, but they have been stored under poorly controlled temperature conditions because their diastatic activity is less than 8 schade. 
Running head: Biochemical and volatile honey profile

Comparatively to our result, (Belhaj et al 2015) and,(Terrab et al 2002) had reported that HMF content ranged between 3.87 to $100 \mathrm{mg} / \mathrm{Kg}$ and 3.8 to $48.44 \mathrm{mg} / \mathrm{Kg}$ respectively forhoney samples produced in TADLA-AZILAL region of Morocco of eucalyptus honey sample from Moroccobut the highest value of HMF content was obtained in Algerian honey samples with 9.6 and $157.4 \mathrm{mg} / \mathrm{kg}$ of honey (Makhloufi 2001).The increase of HMF content may be due to the temperate climate of the country, it was reported HMF production is a natural phenomenon taking place progressively at room temperature and accelerated as temperature increases regardless of Horney nature ( Perdrix, 2003)

Although, honey is thermally processed to eliminate yeast, it could result in product quality deterioration. Uncontrolled heating alters the parameters such as hydroxymethylfurfural (HMF) content and enzyme activity unfavorably. The initial HMF content in different honey types varies drastically and it depends upon the climatic conditions of the region besides other factors. Excessive amount of HMF has been considered as evidence of overheating, causing browning and loss of freshness of honey. ( $\mathrm{R}$ Subramania et al, 2007) (Singh and Bath P.K. 1998). Regarding the relationship between heating and HMF formation in different types of honey,heating temperature and time showed significant effect on HMF formation. Similar studies on effects of thermal treatment of honey were conducted by (Tosi et al, 2002). The authors reported HMF formation during the treatment process did not depend on their initial amount in honey.

They also reported that during thermal processing, the time-temperature combination is very crucial for maintaining the HMF level below the maximum permissible limit (Gupta et al., 1992). In the Other hand(Conrad et al., 2010), report that high level of HMF can cause DNA damage in human cells and contribute to obesity and heart disease. It is worth mentioning that HMF content is not an intrinsic property of honey, so it cannot be used for the determination of botanical origin (Schweitzer et al., 2004). 
Running head: Biochemical and volatile honey profile

Diastase is the natural enzyme ( $\alpha$ and $\beta$ amylase) catalyzing the degradation of $0.01 \mathrm{~g}$ of starch in $1 \mathrm{~h}$ at $40^{\circ} \mathrm{C}$ and then viscosity loss in honey (FurkanYardibi, Gumus T, 2010). Diastase activity in honey depends on the amount of nectar the bee processes at each period, geographic and floral origins of the product (Escuredo, O.and al, 2011), (Diastase activity can be used as an index of aging and temperature abuse, but with precaution, because its variability is high (Gomes, S and $a l, 2010)$.

Diastase in honey converts long-chain sugars to short-chain sugars and the enzymes activity hints with possible heating and/or poor storage conditions(Sourcehttp://www.phadebas.com/areas-of-use/alimentary/diastase-in-honey) .lts sensitivity towards temperature is very high. Diastase activity determination is used as a parameter related to the freshness of honey, to its warming or storing condition (vorlova, L., Pridal, A., 2002):

According to table 2, diastase activity of honey samples ranged from 0.00 and 17.5Schade unit, with an average of 3.5 Schade unit. A limit of 8 units Schade is the minimum limit required by international standards, with a tolerance of 3 Schade units for poor honey, provided that the HMF content does not exceed $15 \mathrm{mg} / \mathrm{kg}$. Around $8.16 \%$ of the samples analyzed (Multiflowershoney from market (ML), AssTh 3 (Thyme honey), FoHe 1(multiflorals) and ZeCa 3(Ceratonia $\mathrm{Z}$ honey)) are above 8 Schade units, they have HMF contents below $40 \mathrm{mg} / \mathrm{kg}$ with the exception of Ceratonia honey ZeCa 3 (Ceratonia Z) which reflects the lack of heating of these honey, however $10,20 \%$ of the honey studied (TzDg 3, FoHe 2, ByOr 3, Fbju 3) had values greater than 3 Schade unit with HMF contents below 15 $\mathrm{mg} / \mathrm{kg}$ which explains why they are naturally low in enzyme. On the other hand $42.85 \%$ of the honey analyzed (PE, BtEup 3, KbCa 3, Ceuc 1, Fbju 1, TiTh 2, AdCa 1, AssTh 2, BtEup 3, TzDg 1, BaOr 1, ZeCa 1, BzEup 3, ByOr 1, BzEup 3, BtEup 2, TiTh 1, BtEup 3, BaOr 2, AssTh 1 and ByOr 2) are below the limit (8 Schade units) with an HMF content of less than 
Running head: Biochemical and volatile honey profile

$40 \mathrm{mg} / \mathrm{kg}$ which lead us to assume they are fresh samples but they have been heated or poorly stored. Atthe end, $38.61 \%$ of the samples are old honey since they recorded higher levels of HMF limit required by standards ( $40 \mathrm{mg} / \mathrm{kg}$ ) and a low diastase activity. Louveaux (1968) reported that the diastase content gradually decreases and tends to zero during aging of honey. Other works (Belhaj et al 2015) reported a range between 6.7and 15Schadeunits inhoney samples collected in TADLA-AZILAL region during the 2014-2015 season. Very low or very high diastase activity in honey are undesirable and high diastase activity explain the formation of acid coming from fermentationsince acids help the enzyme to break down starch (FurkanYardishM ,Gurmus T, 2010).

The main amino acid of honey is proline. The latter is a honey quality trait but it is not used in the Codex Alimentarius 2001. The proline content of examined samples varied between 0.35 $302.15 \mathrm{mg} / \mathrm{kg}$ with an average of $191.10 \mathrm{mg} / \mathrm{kg}$. The post hoc Duncan test classified simples into 20 homogenous subsets which attest an important significant pairwise differences.Cotte et al, (2004) reported that honey has reached maturity when its proline content is greater than $183 \mathrm{mg} / \mathrm{kg}$, and lower values indicate a lack of maturity or freshness or falsification (Petrov, 1974; Won DerOhe et al., 1991). There was $28.57 \%$ of the honey analyzed during this study lacking maturity stage, these samples also had high water content exceeding $20 \%$, except for BaOr 1, TiTh 1, ZeCa 1, MTf and Sy, which_are probably falsified. On the other hand, $71.43 \%$ of the samples were mature, the highest value reported in eucalyptus honey, and the lowest content was observed in synthetic honey(Bosi et al, 1978) and Davies, (1982) reported that proline content could be considered as an indicator of botanical origin.

Results of honey samples color evaluation are given in the table 2. The color of honey samples are shown in table $2 b$. The color of the honey was significantly affected by the storage temperature and period with deterioration at a condition storage temperature. Samples were classified into 20 subsets according to Duncan test $(p<0.05)$. The results of the 
Running head: Biochemical and volatile honey profile

table2bshowed that color value (PFUND) willbe in the range of $390.96 \mathrm{mmPfund}$ to $3 \mathrm{~mm}$

Pfund. The highest value was obtained from Ghana honey but the lowest value from unifloral of citrus (OuledYaich) was observed with $126.58 \mathrm{~mm}$ Pfund. The highest and lowest color intensities were related to multifloral honey from Ghana (387.64 mmPfund andcitrus honey (13.25mmPfund), respectively_Euphorbia, Thymus, Eucalyptus,_Ziziphus lotus, Caralluma europaea and_Caralluma_europaea_honey were significantly different from each other. The honey samples will be classified into 6 groups according to their lightness and darkness.According to these result $34.7 \%$ of honey samples studied here considered dark honey and $12.44 \%$ light honey.Tsigouri at al.,(2004)reported color of 208 samples of Greece honey in the range of 5 and $100 \mathrm{~mm}$ Pfund and the lowerst color for Citrus honeywhich is similar to the results obtained in this study. As reported in many studies( Viuda and al, 2010), the honey color is one of the factors determining its price as well as its acceptance in the world market. Honey from different botanical sources consist of different compositions and concentrationsof pigments mainly polyphenols and carotenoids, flavonoids and long-chain phenolics, and as well as other components like terpene and isoprene (Alvarez, L.M, 2011). Also, Color intensity in honey might also be related to the products resulting from the Maillard reaction (Miotto, D, 2011). The result of table 1 that all honey from different botanical sources consist of different compositions and concentration of pigments mainly polyphenols and carotenoids (Alvarez L M, 2011) and might be affected by geographic characteristic such as mutifloral honey from Ghana with darkness honey (387.6 mmPfund).

\subsection{Total polyphenol content}

Total_phenolics_of honey samples_showed a high significant variability among samples ( $\mathrm{p}<0.001)$. Duncan multiple-range test showed significant pairwise differences with 21 homogenous subsets (table 2). Values ranged from0.58 $\pm 0.2 \mathrm{mg}$ GAE/100g (gallic acid equivalent by 100 gram of extract) for the Citrus $x$ sinensisto $150.35 \pm 1.3 \mathrm{mg}$ GAE/100g for Thymespp honey. The average value was about 50.31 $\pm 2.93 \mathrm{mg}$ GAE/100g. The highest 
Running head: Biochemical and volatile honey profile

content was obtained in multi flowers honey from Ghana with 149.41 $\pm 0.4 \mathrm{mg}$ GAE/100g

(Table 3). The results (Table 3) shows that the total phenolic content were significantlydifferent among the honey samples with $P<0.005$. The highest content of polyphenolic was obtained in honey Thymusspp(70.97 $\pm 1.3 \mathrm{mg}$ GAE/100g) followed by

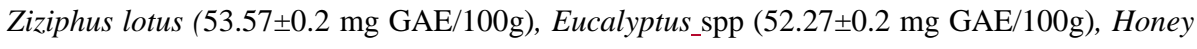
samples from All Flowers Morroco, Ceratonia_siliqua, Caralluma_europaea and finally Citrus $x$ sinensis $($ Table 3)... Significant variation $(\mathrm{p}>0.05)$ was observed between the honey samples from the same botanical origin ad different regions. This implies that the concentration and type of polyphenolic compounds in honey are variable and essentially depend on the geographical, botanical resources and climatic characteristics (Kucuk and al., 2007), they contribute to the appearance and functional properties of honey (Alvarez Suarez and $a l, 2010)$

These results are in concordance to those reported by (Khalil and al 2011) and they were higher than values observed in Spain (2 to $17 \mathrm{mg} \mathrm{GAE} / 100 \mathrm{~g}$ (Thibaut Istasse etal, 2016), . This is expected as properties and composition of honey is strongly affected by various factors including its nectar source, collection season, mode of storage, and harvest technology and conditions (Kaskoniene and Venskutonis, 2010). The phenoliccompounds constitute a good attribute of quality of honey and giving an antioxidant property has a beneficial therapeutic effect. The Thymus ssp honey from Morocco and multifloral honey from Ghana have more nutritional value regarding to polyphenols content.

\subsection{Total flavonoid content}

Total flavonoid contents of the different types of honey are illustrated in Table 3. The results reveal that Thymus spphoney contains a significant amount of flavonoids with $47.18 \pm 2.4 \mathrm{mg}$ $\mathrm{Ru} / 100 \mathrm{~g}$, followed by Euphorbia honey, Caralluma_europaea honey, Ceratonia_siliqua honey, Eucalyptus_spp honey, Ziziphus lotus honey_and multiflorals_Moroccan honey_and 
Running head: Biochemical and volatile honey profile

finally Citrus $x$ sinensis honey. All the Moroccan honey from the different botanical origin shows a lower value than multiflorals honey from Ghana. The components in honey reported to be responsible for its antioxidant effects are flavonoids, phenolic acids, ascorbic acid, catalase, peroxidase, carotenoids, and the products of Maillard reactions. However, the amount and type of these antioxidants are largely dependent on the floral source, honey variety and a correlation between antioxidant activity and total phenolic content has been established (Khalil and Alam, 2011); (Gheldofetal., 2002). The results are in agreement with those of previous studies, were authors found that honey samples with higher polyphenol content also yield high flavonoid levels (Moniruzzaman and al., 2013; (Khalil and al., 2012). Most phenolic compounds are in the form of flavonoids. They make up a great family of plant phenolic pigments and are effective in aroma of honey(Escuredo, Oand al, 2012). The quantity and type of these identified in honey vary according to the botanical source. In contrast, darker honey contain higher amounts of flavonoids than bland honey, as well as greater antioxidant capacity (Medic and al., 2004).The concentration and type of flavonoids is strongly affected by the floral origin of honey (Ulusoy, E and $a l, 2010$ )

\subsection{Total carotenoid content}

Total carotenoids contents of the studied honey are shown in Table 3. A close look at the results shows always that Thymus has the highest content of_carotenoids, followed_by Euphorbia, Ceratonia_siliqua, Citrus x sinensis, Ziziphus lotus, Eucalyptus_spp and finally multifloral_honey from Moroccan. Rodriguez-Amaya, (2001); Faciullino et al., 2006 reported that the amount of carotenoids in honey is influenced by the growing conditions and maturity of the fruits, and the flowers visited by the bees. It was also cited that honey color is not attributed only to carotenoids but to the presence of phenolic compounds and depend on the flower origin. These authors found a high correlation between polyphenol content and honey color (Amiot et al., 1989). 
Running head: Biochemical and volatile honey profile

\section{Table 3}

Biochemical proprieties of local and foreign honey samples. The mean, standard deviation and the variable ranges are reported according to their botanical origin

\begin{tabular}{lccc} 
Type of honey & $\begin{array}{c}\text { Phenolics } \\
\text { compounds } \mathrm{mg} \\
\text { GAE/100g }\end{array}$ & $\begin{array}{c}\text { Flavonoids compounds } \\
\mathrm{mg} \mathrm{Ru} / 100 \mathrm{~g}\end{array}$ & $\begin{array}{c}\text { Carotenoids compounds } \\
\mathrm{mg} \beta \text {-carotene E/100g }\end{array}$ \\
\hline Carallumaeuropaea & $49.56 \pm 0.42$ & $31.15 \pm 0.1$ & $15.09 \pm 0.3$ \\
\hline Eucalyptus spp & $52.27 \pm 0.2$ & $29.4 \pm 0.2$ & $31.86 \pm 0.6$ \\
\hline Thymus spp & $70.97 \pm 1.3$ & $47.18 \pm 2.4$ & $74.94 \pm 3.08$ \\
\hline Citrus x sinensis & $41.48 \pm 0.2$ & $10.43 \pm 0.1$ & $43.1 \pm 0.2$ \\
\hline Ceratoniasiliqua & $51.88 \pm 0.2$ & $30.85 \pm 0.01$ & $56.17 \pm 1.5$ \\
\hline Ziziphus lotus & $53.57 \pm 0.2$ & $17.61 \pm 0.4$ & $36.49 \pm 0.1$ \\
\hline Euphorbia & $46.33 \pm 0.4$ & $39.1 \pm 2.05$ & $66.39 \pm 2.02$ \\
\hline Multifloralhoney from & $53.57 \pm 0.8$ & $17.75 \pm 0.1$ & $18.04 \pm 0.6$ \\
\hline Morocco & & & $40.76 \pm 0.7$ \\
\hline Multifloral honey from Ghana & $149.41 \pm 0.4$ & $58.28 \pm 2.6$ & $09.0 \pm 0 / 2$ \\
\hline Honey of Sugar syrups (SY) & $0.73 \pm 0.2$ & $0.043 \pm 0.01$ & $36.67 \pm 6.5$ \\
\hline Multifloral honey from France & $17.98 \pm 0.5$ & $21.38 \pm 7.1$ &
\end{tabular}

* Data are reported as means \pm SE for three replications.

\subsection{Antioxidant activityFree radical scavenging activity}

In evaluating the radical-scavenging potential of a sample including honey, the DPPH assay is frequently used. Usually, a high DPPH scavenging activity reflects high levels of antioxidant potential. The results of DPPH radical scavenging percentage and quantities of the Moroccan honey samples (expressed $\%$ and $\mathrm{mg}$ ) showed inTable 4 . The antioxidant activities of honey samples ranged from $21.16 \pm 0.5$ for Thymusspp honey and 36.54 \pm 0.4 ET/100g from mutifloral honey from Ghana. The mean DPPH radical-scavenging activity of the investigated honey samples was $19.58 \%$. The result showed that all samples honey had antioxidant activities and Euphorbia honey possessed the highest antioxidant activitie with $38.98 \pm 0.4 \mathrm{Eq} \mathrm{T} / 100 \mathrm{~g}$ for Citrus $x$ sinensis honey and Ziziphus lotus honey (38.82 $\pm 0.6 \mathrm{Eq} \mathrm{T} / 100 \mathrm{~g})$ 
Running head: Biochemical and volatile honey profile

The honey samples of Thymus_spp again exhibited the highest DPPH radical-scavenging activity $(50.23 \%)$ which could be attributed to its higher phenolic acid and flavonoid content, as it has been reported that the antioxidant potential of honey is directly proportional to the amount of phenolic acids and flavonoids present (Beretta et al., 2005). The difference in the antioxidant activity of various types of honey result from antioxidant activity compounds especially phenolic content, carotenoids and flavonoids (FurkanYardibi M et al, 2010); (Ferreira et al. 2009). The lower quantities of antioxidants value indicate a higher DPPH free radical scavenging activity which was noted for the Thymus_spp with $21.16 \pm 0.5 \mathrm{mg}$ ET/100g (Table 3). A significant difference $(\mathrm{p}<0.05)$ between all honey samples from different flowers origins was found. But, higher correlations were observed between the DPPH radical scavenging activity percentage and the total polyphenol and flavonoids respectively $(r=0.987$, $\mathrm{r}=0.952$ ). According to (Beretta etal, 2005), honey with dark color have a high antioxidant activity such asthe result obtained for Thymus honey. This type of honey has the largest amount of free radical accepting compounds and the greatest antioxidant potential. These results are in perfect correlation and accordance with the works of (Alvarez-Suarez et al. 2010), (Sant'Ana et al. 2012) and (Ferreira et al. 2009) who found that there is a positive correlation between total polyphenols, and total flavonoids.

Table 4

DPPH-Freeradical-scavenging activitiesusing DPPH method (mg trolox equivalent/ $100 \mathrm{~g}$ of exract) of the different honey from different botanical origin

\begin{tabular}{ccc}
\hline Type of honey & Inhibition percentage \% & $\begin{array}{c}\text { Quantities mg } \\
\text { TroloxEq.ET/100g }\end{array}$ \\
\hline Carallumaeuropaea & $29.02 \pm 0.01$ & $31.09 \pm 2.2$ \\
\hline Eucalyptusspp & $16.78 \pm 1.19$ & $33.07 \pm 0.9$ \\
\hline Thymusspp & $50.23 \pm 1.87$ & $21.16 \pm 0.54$ \\
\hline Citrus $\boldsymbol{x}$ sinensis & $12.26 \pm 0.52$ & $38.98 \pm 0.39$ \\
\hline Ceratoniasiliqua & $23.56 \pm 0.39$ & $36.27 \pm 1.87$ \\
\hline Ziziphus lotus & $12.23 \pm 0.0615$ & $38.82 \pm 0.57$ \\
\hline Euphorbia & $31.79 \pm 1.12$ & $29.79 \pm 0.42$ \\
\hline $\begin{array}{c}\text { Multiflorals honey from } \\
\text { Morocco }\end{array}$ & $25.86 \pm 0.90$ & $32.56 \pm 0.32$ \\
\hline
\end{tabular}


Running head: Biochemical and volatile honey profile

\begin{tabular}{ccc}
\hline $\begin{array}{c}\text { Multiflorals honey from } \\
\text { Ghana }\end{array}$ & $17.36 \pm 0.07$ & $36.54 \pm 0.36$ \\
\hline $\begin{array}{c}\text { Multiflorals honey } \\
\text { France }\end{array}$ & $18_{:-24 \pm 3_{-;}, 93}$ & $37.45 \pm 0.24$ \\
\hline Honey of sugar syrups & $18_{. ;}, 45 \pm 3_{-;}, 62$ & $38.23 \pm 0.16$
\end{tabular}

(SY) replications

* Data are the mean of three replicationsAverage values \pm standard errors of mean of three

\subsection{Volatile compounds characterization}

HS-SPME method combined to GC-MS analysis allowed identification of about $30 *$

compounds in honey samples which relative amounts are determinated based on percentage $\underline{\text { area. Identified compounds include alcohols, aldehydes, ketones, acids, esters, terpenes and }}$ nitrogen compounds are shown in Table 5.

\subsection{0lfacto-gustatory profile and volatile compounds characterization}

Around 30 major volatile compounds were identified and semi quantified in the volatile fractions of honey samples, including alcohols, aldehydes, ketones, acids, esters, terpenes and nitrogen compounds. The average values, standard deviation, and the ANOVA results of the volatile compounds analysed in both types of honey are shown in Table 5.

\section{Table 5}

Main relative volatile composition (\%) characteristics of each honey from different floral origin

\begin{tabular}{|l|l|l|l|}
\hline \multicolumn{1}{|c|}{ Type of honey } & Compound & $\begin{array}{r}\text { CAS } \\
\text { number }\end{array}$ & $\begin{array}{l}\text { Percentage } \\
\%\end{array}$ \\
\hline Caralluma europaea & Ethanol & $64-17-5$ & 39.2 \\
\cline { 2 - 4 } & lilac aldehyde A & $53447-45-3$ & 8.6 \\
\cline { 2 - 4 } & lilac aldehyde D & $3447-48-6$ & 6.6 \\
\cline { 2 - 4 } & nonanoic acid & $112-05-0$ & 8.7 \\
\cline { 2 - 4 } & benzoic acid, & $65-85-0$ & 2.0 \\
\hline Eucalyptus spp & ethanol & $64-17-5$ & 18.5 \\
\cline { 2 - 4 } & lilac aldehyde C & $78-59-1$ & 14.5 \\
\cline { 2 - 4 } & benzeneacetaldehyde & $122-78-1$ & 6.3 \\
\cline { 2 - 4 } & benzeneethanol & $60-12-8$ & 11.0 \\
\cline { 2 - 4 } & nonanoic acid & $112-05-0$ & 5.7 \\
\hline
\end{tabular}

Formatted: Font: Times New Roman, $12 \mathrm{pt}$

Formatted: Indent: Left: 0 ", Line spacing: 1.5 lines

Formatted: Indent: Left: 0 ", Line spacing: Double 


\begin{tabular}{|c|c|c|c|}
\hline & ethanol & $64-17-5$ & 38.5 \\
\hline \multirow[t]{5}{*}{ Thymus spp } & 8-hydroxylinalool & $103619-06-3$ & 3.9 \\
\hline & ethyl nonanoate & $123-29-5$ & 10.4 \\
\hline & lilac aldehyde $\mathrm{C}$ & $53447-47-5$ & 6.1 \\
\hline & benzeneacetic acid & $103-82-2$ & 2.4 \\
\hline & ethanol & $64-17-5$ & 20.4 \\
\hline \multirow[t]{5}{*}{ Citrus $x$ sinensis } & furfural & $98-01-1$ & 6.3 \\
\hline & benzeneethanol & $60-12-8$ & 14.5 \\
\hline & nonanoic acid & $112-05-0$ & 10.4 \\
\hline & 2,5-furandicarbaldehyde & $823-82-5$ & 2.2 \\
\hline & ethanol & $64-17-5$ & 12.7 \\
\hline \multirow[t]{5}{*}{ Ceratonia siliqua } & furfural & $98-01-1$ & 14.4 \\
\hline & 2,3-butanediol & $513-85-9$ & 4.5 \\
\hline & nonanoic acid & $112-05-0$ & 10.5 \\
\hline & octanoic acid & $124-07-2$ & 7.7 \\
\hline & ethanol & $64-17-5$ & 13.3 \\
\hline \multirow[t]{5}{*}{ Ziziphus lotus } & acetic acid & $64-19-7$ & 9.5 \\
\hline & (z)-linalool oxide & $5989-33-3$ & 6.3 \\
\hline & furfural & $98-01-1$ & 8.1 \\
\hline & pentanoic acid & $109-52-4$ & 13.2 \\
\hline & ethanol & $64-17-5$ & 11.1 \\
\hline \multirow[t]{5}{*}{ Euphorbia } & furfural & $98-01-1$ & 8.9 \\
\hline & Isoborneol & $10385-78-1$ & 9.4 \\
\hline & 2,5-furandicarbaldehyde & $823-82-5$ & 14.4 \\
\hline & anisaldehyde & $50984-52-6$ & 7.5 \\
\hline & beta myrcene & $123-35-3$ & 14.1 \\
\hline \multirow{4}{*}{$\begin{array}{l}\text { Multifloral honey } \\
\text { Morocco }\end{array}$} & dl-limonene & $138-86-3$ & 6.4 \\
\hline & (z)-linalool oxide & $5989-33-3$ & 13.4 \\
\hline & sorbic acid & $22500-92-1$ & 16.3 \\
\hline & pentanoic acid & $109-52-4$ & 4.5 \\
\hline Type of honey & Compound & CAS number & Percentage $\%$ \\
\hline \multirow[t]{2}{*}{ Carallumaeuropaea } & Ethanel & 64175 & 39.2 \\
\hline & lilac aldehyde $A$ & $53447-45-3$ & 8.6 \\
\hline
\end{tabular}

Running head: Biochemical and volatile honey profile 
1

2

3

4

Running head: Biochemical and volatile honey profile

\begin{tabular}{|c|c|c|c|}
\hline & lilac aldehyde $D$ & $53447-486$ & 6.6 \\
\hline & nonanoic acid & $112-05-\theta$ & 8.7 \\
\hline & benzoic acid, & $65-85-\theta$ & 2.0 \\
\hline \multirow[t]{6}{*}{ Eucalyptus spp } & ethanel & 64175 & 18.5 \\
\hline & lilac aldehyde $C$ & 78591 & 14.5 \\
\hline & benzeneacetaldehyde & 122784 & 6.3 \\
\hline & benzeneethanel & 60128 & 5.7 \\
\hline & nenanoic acid & $11205-\theta$ & 41.0 \\
\hline & ethanol & $64-17-5$ & 38.5 \\
\hline \multirow[t]{5}{*}{ Thymus-spp } & 8 hydroxylinatoet & $103619-063$ & 3.9 \\
\hline & ethyl nonanoate & $12329-5$ & 10.4 \\
\hline & lilac aldehyde $C$ & $53447-47-5$ & 6.1 \\
\hline & benzeneacetic acid & $103-822$ & 2.4 \\
\hline & ethanet & $64-175$ & 20.4 \\
\hline \multirow[t]{5}{*}{ Citrus $\mathrm{x}$ sinensis } & furfural & $98-01-1$ & 6.3 \\
\hline & benzeneethanel & 60128 & 14.5 \\
\hline & nonanoic acid & $11205-\theta$ & 10.4 \\
\hline & 2,5-furandicarbaldehyde & $823-82-5$ & 2.2 \\
\hline & ethanel & 64175 & 12.7 \\
\hline \multirow[t]{5}{*}{ Cerateniasiliqua } & furfural & $98-014$ & 14.4 \\
\hline & 2,3-butanediol & $513-85-9$ & 4.5 \\
\hline & nonanoic acid & $11205-\theta$ & 10.5 \\
\hline & ectanoic acid & $124-07-2$ & 7.7 \\
\hline & ethanel & $64-17-5$ & 13.3 \\
\hline \multirow[t]{5}{*}{ Ziziphus lotus } & acetic acid & 64197 & 9.5 \\
\hline & (z) linaleoloxide & $5989-33-3$ & 6.3 \\
\hline & furfural & $98-01-1$ & 8.1 \\
\hline & pentaneic acid & $109-524$ & 13.2 \\
\hline & ethanet & 64175 & 41.4 \\
\hline \multirow[t]{4}{*}{ Euphorbia } & furfural & $98-01-1$ & 8.9 \\
\hline & Isoborneol & $1038578-1$ & 9.4 \\
\hline & 2,5-furandicarbaldehyde & $823-825$ & 14.4 \\
\hline & anisaldehyde & $50984-52-6$ & 7.5 \\
\hline
\end{tabular}


Running head: Biochemical and volatile honey profile

\begin{tabular}{llcc}
\hline & betamyrcene & $123-35-3$ & 14.4 \\
\hline Multifloral honey Moroce & dl-limonene & $138-86-3$ & 6.4 \\
\cline { 2 - 4 } & (z) linalool oxide & $5989-33-3$ & 13.4 \\
\cline { 2 - 4 } & sorbic acid & $22500-92-1$ & 16.3 \\
\cline { 2 - 3 } & pentanoic acid & $109-52-4$ & 4.5 \\
\hline
\end{tabular}

In the different type of analysed_honey, a lot of compounds were identified: including 58 in Citrus $x$ sinensis honey, 65 in Eucalyptus_spp honey, 79 in Thymus_spp honey, 63 in Ceratonia_siliqua, 64 in mutifloral honey, 67 in Caralluma_europaea honey 73 in Ziziphus lotus honey and 93 in Euphorbia honey. Some of the compounds, present in medium and even high relative amounts, were not quantified for different reasons.Although small quantities of trimethyl phenols have been reported in some honey samples (Castro-Vazquez, PerezCoello, \&Cabezudo, 2003), their origin is unclear and they were not taken into account. Furfural depends on heat treatment and ethanol may be related to the development of yeasts (Beckh, Wessel, \&Luellman, 2005); (Papoff, Campus, Floris, \& Farris, 1995). The origin of 2-ethyl hexanoic acid is also uncertain; although this compound has been identified among volatile components of wines and beers (Vinh, Schwartz and, \& Moll, 1981).

Identified compounds belonged to different chemical classes as follows: alcohols: e.g. ethanol, 1-propanol, 2-methyl-, 2,3-butanediol; phenols: e.g. phenol, 3,4,5-trimethyl-; ketones: e.g. acetone, acetophenone, butyrolactone; organic acids: e.g. formic acid, acetic acid, butanoic acid; esters: e.g. ethyl acetate, methyl salicylate; aldehydes: e.g. butanal, 3methyl-, furfural, nonanal; aliphatic hydrocarbons: e.g. octane, nonane; aromatic hydrocarbons: e.g. toluene, vinylobenzene; hydrocarbons cyclic: e.g. d-limonene. Among the identified compounds, 41 were found in all analysed samples, however, their mutual proportions were substantially different. The main volatile compounds of each type of honey are presented in the table 5 . 
Running head: Biochemical and volatile honey profile

In addition, in each type of honey samples, there is some compounds that are unique of each

type of honey, which could be considered as biomarkers of every type of samples of honey

(Table 5)

Comparing the results presented above with other published data (Verzera et al., 2001);Piasenzotto et al., 2003), the same regularity is found. Most of the components were identified in all of the analyzed honey, but the ratios between the particular components were very different for each different floral origin. Similarly, in each of analyzed honey there were compounds found which were not present in other honeytypes. In this research we have found some compounds that could be considered like biomarkers for botanic origins of honey as reported in table 6.

Table.6: Biomarkers volatile compounds (\%) characteristics classified by the floral type

\begin{tabular}{|c|c|c|c|}
\hline Unifloral honey types & Compounds & CAS number & Range\% \\
\hline \multirow[t]{2}{*}{ Carallumaeuropaea } & 8-hydroxylinalol & $103619-06-3$ & $0.3-3.9$ \\
\hline & lilas aldehydes & $53447-47-5$ & $16.1-80.3$ \\
\hline Eucalyptus spp & nonanal & 124-19-6. & $6.6-18.0$ \\
\hline Thymus spp & 2,4-diméthoxybenzaldéhyde & $613-45-6$ & $0.0-0.10$ \\
\hline Euphorbia & $\begin{array}{l}\text { 2-hydroxy-3,5,5-triméthyl-2- } \\
\text { cyclohexan-1,4-dione }\end{array}$ & $78-59-1$ & $1.2-5.1$ \\
\hline \multirow[t]{2}{*}{ Ceratoniasiliqua } & (z)-linalool oxide & $5989-33-3$ & $9.1-45.8$ \\
\hline & hotrienol & $20053-88-7$ & $2.2-3.2$ \\
\hline Carallumaeuropaea & $2,2,4,6,6$, pentamethylheptane & $13475-82-6$ & $0.0-0.10$ \\
\hline Ziziphus lotus & $\begin{array}{l}\text { 1,2-dihydro-1,1,6- } \\
\text { trimethylnaphthalene }\end{array}$ & $30364-38-6$ & $0.1-0.2$ \\
\hline
\end{tabular}


Running head: Biochemical and volatile honey profile

\section{Principal component analysis}

\section{Physico-biochemical proprieties}

Results of dimension reduction analysis based in all physicochemical and biochemical compounds analysis are shown in table 7-a and figure 1. Thus, the first two dimensions of PC analysis expressed $34.91 \%$ and $23.42 \%$ of the total variance explained (58.33\%). In our case, we estimate that this percentage is relatively important regarding the number and the quality of variables (Figure 1). Honey color, total phenols, total flavonoids and total carotenoids are positively and strongly correlated to the first principal component " $\mathrm{PCl}$ " $(\mathrm{r}=0.92, \mathrm{r}=0.67, \mathrm{r}=$ 0.91, $\mathrm{r}=0.56$ ); However, the radical scavenging activity was negatively correlated to the PC1 $(r=-0.48) . H M F$, Proline and Diastase were the most discriminant variables for the second principal component have negative scores for this discriminant function ( $r=0.7, r=0.79$ and $\mathrm{r}=0.73$ respectively).

\section{Table.7.a}

Squared cosines of the evaluated variables

\begin{tabular}{lrc}
\hline & \multicolumn{2}{c}{ Principal components $(\mathrm{PC})$} \\
\cline { 2 - 3 } & $\mathrm{PC} 1(34.91 \%)$ & $\mathrm{PC} 2(23.42 \%)$ \\
\hline HMF & 0.174 & $\mathbf{0 . 7 0 1}$ \\
\hline Proline & 0.167 & $\mathbf{0 . 7 9 5}$ \\
\hline Color & $\mathbf{0 . 9 2 4}$ & 0.074 \\
\hline Diastase & -0.091 & $\mathbf{0 . 7 3 4}$ \\
\hline Phenols & $\mathbf{0 . 6 7 1}$ & 0.020 \\
\hline Flavonoids & $\mathbf{0 . 9 1 6}$ & 0.105 \\
\hline Carotenoids & $\mathbf{0 . 5 6 6}$ & 0.125 \\
\hline Free Antioxidant Activity & $\mathbf{- 0 . 4 7 8}$ & 0.349 \\
\hline
\end{tabular}


Running head: Biochemical and volatile honey profile

Examining the graphical distribution of the honey samples on the reported plot (figure.1) using the $\mathrm{PC} 1$ and $\mathrm{PC} 2$ first and the second principal components $\underline{\mathrm{PC} 1}$ and $\mathrm{PC} 2$ as coordinate axes, clustering of all evaluated honey samples based on their physico-biochemical proprieties has been performed using principal component analysis (PCA) that revealed four mean homogeneous and distinctive groups. Hence, the first group (G1) contains 17 honey samples that have the highest values of free radical scavenging activity, diastase activity and proline content where the values ranged from 36 to $43 \%$, from 3 to 17 Schade units and from 198 to $267 \mathrm{mg} / \mathrm{kg}$ respectively. The second group contains only three honey samples which are Thyme and Euphorbia (TiTh3, BtEup2 and BtEup3). This group combined particularly the highest concentrations in Total phenols (from 54 to $194 \mathrm{mg}$ EAG/100 g), total flavonoids

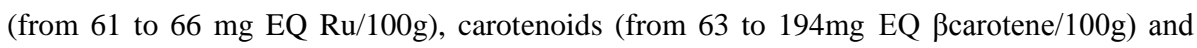
highest color values (from 355 to 395Pfund). The third group clusters with nine honey samples and is negatively correlated to the second component $(23.24 \%)$. This group is related to the samples of honey that relatively have an important amount of hydroxymethylfurfural (from 1.5 to $5 \mathrm{mg} / \mathrm{kg}$ ) but low diastase activity and low to average free antioxidant activity. The last group (G4) contains a large number of collected honey samples (Twenty) that are characterized by an average values of bio-physicochemical markers used in this work.

Examining the graphical distribution of the honey samples on the reported plot (figure.1) using the PC1 and PC2 principal components as coordinate axes, a natural separation of the four honey groups of different botanical origin was found. The principal component analysis (PCA) revealed four mean homogeneous and distinctive groups. Hence, the first group (G1) contains 17 honeysamples that have the highest values of free radical scavenging activity, diastase index and proline content where the values ranged from 36 to $43 \%$, from 3 to 17 Schade units and from 198 to $267 \mathrm{mg} / \mathrm{kg}$ respectively. The second group contains only three honey samples which are Thyme and Euphorbia (TiTh3, BtEup2 and BtEup3). This group 
combined particularly the highest concentrations in Total phenols (from 54 to $194 \mathrm{mg}$ EAG/100 g), total flavonoids (from 61 to $66 \mathrm{mg}$ EQ Ru/100g), carotenoids (from 63 to 194mg EQ $\beta$ carotene/100g) and highest color values (from 355 to 395Pfund). The third group clusters with nine honeysamples and is negatively correlated to the second component $(23.24 \%)$. This group is related to the samples of honey that relatively have an important amount of hydroxymethylfurfural (from 1.5 to $5 \mathrm{mg} / \mathrm{kg}$ ) but low diastase activity and low to average free antioxidant activity. The last group (G4) contains a large number of collected honey samples (twenty) that are characterized by an average values of bio-physicochemical markers used in this work.

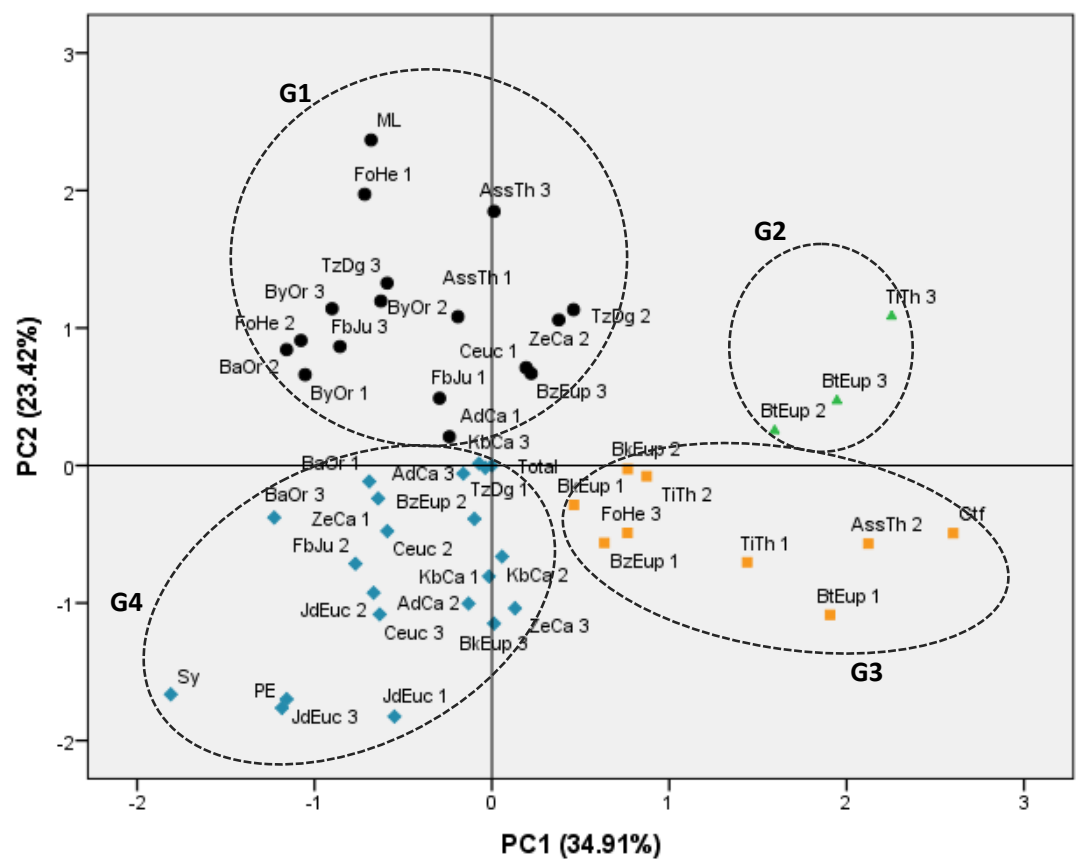

*Code samples are reported in the table 1.

Figure 1.Principal component analysis on individuals (total inertia $=58.33 \%$ )

\section{Volatile compounds}


Running head: Biochemical and volatile honey profile

7595 For depth discrimination of honey samples, a clustering based on the honey volatile 8

constituents was performed using their botanical origins as a selection variable. The principal myrcene, pentanoic acid and octanoic acid are the most discriminantvariable ( $r=0.962)$ for the first principal component PC1 (34.91\%), while ethanol (0.848), furfural (-0.721), benzoic acid (0.583), 2,5-furandicarbaldehyde (-0.564) and isoborneoland anisaldehyde $(-0.533)$ were the variables that recorded the strongest correlations with the second principal component PC2 (figure. 2a).

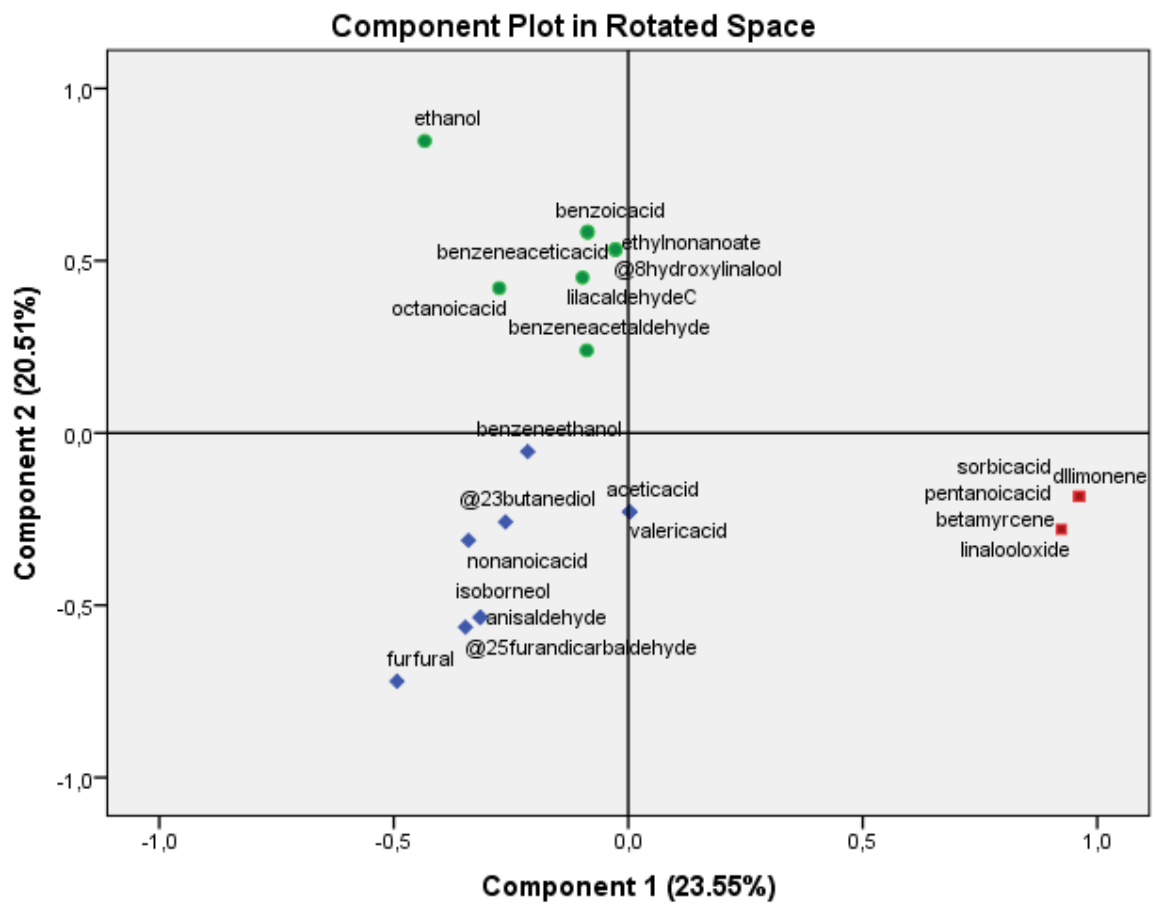

Figure 2a.Principal component analysisofvolatilescompounds contained in Moroccanhoney samples 
Running head: Biochemical and volatile honey profile

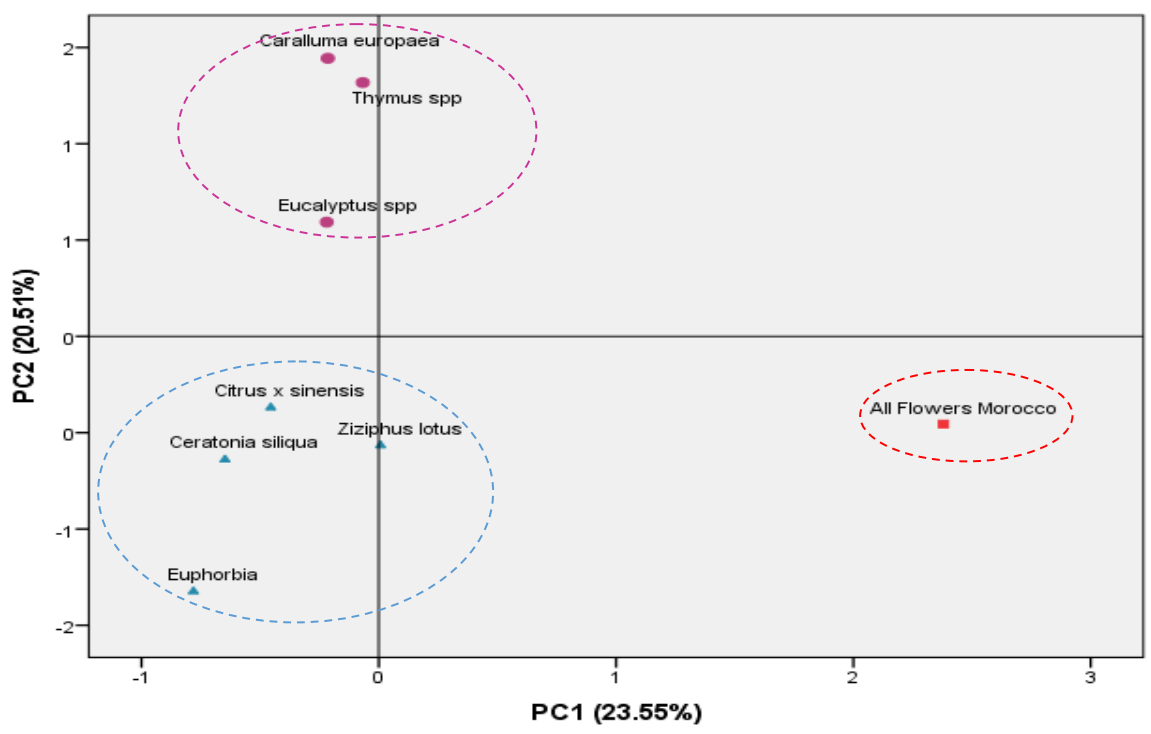

Figure 2b.Principalcomponent analysis of different botanical originsof Moroccan honey samples according to their volatiles compounds.

The principal component analysis on individuals (Figure.2b), which considered floral origin as main variable of selection, revealed three homogeneous groupsof different botanical origins honeyaccording to theiramounts in volatiles. The first group contains 3 honey botanical origins that are Carallumaeuropaea, Thymus spp et Eucalyptus spp. Theselatter,seem to have a similar or closeamounts of some volatile compounds that reveled positively correlated to the second component (ethanol, benzoic acid,benzeneacetic acid, ethyl nonanoate, 8hydroxylinalool, octanoic acid, lilac aldehyde $\mathrm{C}$ and benzeneacetaldehyde). The second group cutlers the following floral origins of honey: the citrus sinensis, ziziphus lotus, ceratoniasiliqua and Euphorbiahoney. These latter are the only honey types that present furfural compound, where the concentrations varied from 6.3 to $14.4 \%$. Furthermore, it contains the only two floral origins (citrus sinensis andceratoniasiliqua) that recorded a 
Running head: Biochemical and volatile honey profile

presence of nonanoic acid where the concentrations were very close (10.4 and $10.5 \%$ respectively).The other discriminant variables of this group are: benzeneethanol, acetic acid, 2,3-butanediol, valeric acid, isoborneol, anisaldehyde and 2,5-furandicarbaldehyde that shown to be negatively correlated to the two principal component. The mutifloral honey samples from Morocco have been largely distinguished from the other floral origins of honey. This botanical origin has a very particular profile that makes it an independent group that is typically characterized by the following compounds: beta myrcene, sorbic acid, dl-limonene, pentanoic acid. It also recorded the highest concentration of linalooloxide (13.4\%). The similarity between honey samples of different origins isprobably due to the pollen origin or to the honey bee farmingas well as similar climatic conditions of the area where honey bees are farmed. PCA results suggested that the clustering method based on volatiles compounds data could provide useful information to achieve a botanical classification for the investigated honey.

Indeed, this classification is due to the composition in volatile biomarkers and their amounts, in addition to their resemblances toward each floral origin of honey. The results of the honey samplesclassification based on their physico-biochemical and volatile compounds allowed us to highlight the importance to conjugate this two approaches in order to assess the quality honey samples that are mainly present at the national market, and also to classify them based on the pollen sources regardless their geographical origins. 
Running head: Biochemical and volatile honey profile

\section{Conclusion}

843

9644

$10_{45}$

11

12646

13

14647

15

$16^{648}$

17

$18^{649}$

19

$20^{650}$

$21_{651}$

22

23552

24

25653

26

27654

28

$29^{655}$

30

$31^{656}$

32657

33

34558

35

36559

37

3860

39

$4 \odot^{61}$

41

$42^{662}$

$43_{663}$

44

45

46

47

48

49

50

51

52

53

54

55

56

57

58

59

60

61

62

63

64

65

In the present study, 47 Moroccan honey from different regions and botanical origin and with

2 foreign ( Ghana and France) were unprecedentedly investigated for their bioactive and volatile compounds, such as total phenols, total flavonoids and carotenoids contents, and antioxidant activity using DPPH method, the results point out and show that the honey samplesfrom different geographical and botanical origins were characterized by the prevalence of total bioactive molecules which have a great eco-industrial interest for the applications of those contents in food processing, cosmetics and pharmaceutical purposes. Honey samples revealed also an excellent antioxidant property which is due to the concentration of phenolic compounds. Volatile compounds, of Moroccan honey from uncommon botanical origins have been studied by SMPE-GC/MS. Although the results obtained are only indicative, several compounds were identified and, some of them was reported for the first time. Those compounds could be clearly related to the floral origin of the samples. SPME-GC/MS seems to be a useful tool for the determining of botanical and geographical origin of honey, so it is necessary to perform more detailed investigations, including a larger number of honey samples from various botanical sources. In general, the analytical results obtained for the honey samples indicate the products' high quality. The determination of physico-biochemical parameters and volatiles compounds content in combination with modern statistical techniques can be a useful tool for honey discrimination and classification. 


\section{Author contributions}

\begin{tabular}{ll}
\hline Author & Contribution \\
\hline Hanine & Study Conception and design \\
& Drafting of manuscript \\
& Analysis and interpretation of data \\
\hline Fauconnier & Acquisition of data relative to SPME-CG/MS analysis \\
& Drafting of manuscript \\
\hline Kenne & Acquisition of data relative to SPME-CG/MS analysis \\
& Drafting of manuscript \\
\hline Rizki & Acquisition of data relative to physicochemical analysis \\
\hline Euradi & Acquisition of data relative to biochemical analysis \\
\hline Hssaini & Drafting of manuscript \\
& Statistical Analysis and interpretation of data \\
& Drafting of manuscript \\
& Critical revision
\end{tabular}


Running head: Biochemical and volatile honey profile

Alvarez, L.M. (2011),Honey Proteins and Their Interaction with Polyphenols; Faculty of Mathematic and Sciences, Brock University: St. Catharines, Ontario,

Alvarez-Suarez, J.M.; Tulipani, S.; Díaz, D.; Estevez, Y.; Romandini, S.; Giampieri, F.; Damiani, E.; Astolfi, P.; Bompadre, S.; Battino, M. (2010), Antioxidant and Antimicrobial Capacity of Several Monofloral Cuban Honey and Their Correlation with Color, Polyphenol Content and Other Chemical Compounds. Food and Chemical Toxicology, 48 (8), 2490-2499.

Alvarez-Suarez, J.M., Giampieri, F., Gonzalez-Paramas, A.M., Damiani, E., Astolfi, P., MartinezSanchez, G., Bompadre, S., Quiles, J.L., Santos-Buelga, C., Battino, M., (2012). Phenolics from monofloralhoney protect human erythrocyte membranes against oxidative damage. Food and Chemical Toxicology 50, 1508- 1516.

Amiot, M. J., Aubert, S., Gonnet, M., \&Tacchini, M. (1989). Les composés phénoliques des miels : étude préliminaire sur l'identification et la quantification par familles. Apidologie, 20(2), 115-125.

Rodriguez-Amaya, D.B.A., (2001). Guide to Carotenoid Analysis in Foods.International Life Sciences Institute Press, 1-71.

Anklam E. (1998)- A review of the analytical methods to determine the geographical and botanical origin of honey. Food Chemistry., 63, 549-562.

Beckh, G., Wessel, P., \&Luellman, C. (2005). A contribution to yeasts and their metabolic products as natural components of honey. Part 3. Contents of ethanol and glycerol as quality parameters. Deutsche Lebensmittel-Rundschau, 101, 1-6.

BelhajO ,Oumato.J , Zrira.S, (2015), Étude physico-chimique de quelques types de miels marocains, Rev. Mar. Sci. Agron. Vét. 3 (3):71-75

Beretta, G., Granata, P., Ferrero, M., Orioli, M., Facino, R.M., (2005). Standardization of Antioxidant Properties of Honey by a Combination of Spectrophotometric/Fluorimetric Assays and Chemometrics. AnalyticaChimicaActa 533, 185-191.

Bertoncelj, J., Dobersek, U., Jamnik, M., Golob, T., (2007). Evaluation of the Phenolic Content, Antioxidant Activity and Colour of Slovenian Honey. Food Chemistry 105, 822-828.

Bogdanov, S., Rouff, K., Oddo, L.P., (2004). Physico-chemical methods for the characterization of unifloral honey: a review. Apidologie 35 (4), 275-282.

Bosi G., Battaglini M. (1978) Gas analysis of free and protein amino acids in some unifloralhoney, J. Apic. Res. 17, 152-166

Codex Alimentarius Commission (2001b) Codex Standard 12, Revised Codex Standard for Honey, Standards and Standard Methods 11.

CorbellaE.andcozzolinod.(2006).classification of the floral origine of uruguayan honey by chemical and physical characteristics combined with chemometrics. Lebensm-wiss.utechnal.,39:534-539

Castaldo, S. \&Capasso, F. (2002). Propolis, an old remedy used in modern medicine. Fitoterapia, 73, S1-S6. 
Running head: Biochemical and volatile honey profile

Castro-Vazquez, L., Perez-Coello, M. S., \&Cabezudo, M. D. (2003). Analysis of volatile compounds of rosemary honey. Comparison of different extraction techniques. Chromatographia, 57, 227-233.

Conrad R. High Fructose Corn Syrup and hydroxymethylfurfural. [Online] 2010 June; Available from: URL: http://www.beeculture.com

Cotte J.F., Casabianca H., Giroud B., Albert M., Lheritier J., Grenier-Loustalot M.F. (2004) Characterization of honey amino acid profiles using high-pressure liquid chromatography to control authenticity, Anal. Bioanal. Chem. 378, 1342-1350.

De la Fuente E., Martinez-Castro I., Sanz J. (2005)- Characterization of Spanish unifloralhoney by solid phase microextraction and gas chromatography-mass spectrometry. Journal of Separation Science. 28, $1093-1100$

Davies A.M.C., Harris R.G. (1982) Free amino acid analysis of honey from England and Wales: application to the determination of the geographical origin of honey, J. Apic. Res. 21, 168-173

Djeridane A., Yousfi M., Nadjemi B., Boutassouna D., Stocker P. and VIDAL N., (2006) Antioxidant activity of some Algerian medicinal plants extracts containing phenolic compound. Food Chem, 97, 654-660.

Escuredo, O.; Seijo, M.C.; Fernández- González, (2011), M.Descriptive Analysis of Rubus Honey from the North-West of Spain. International Journal of Food Science and Technology , 46(11), 23292336

Estevinho L, Pereira AP, Moreira L, Dias LG, Pereira E. (2008), Antioxidant and antimicrobial effects of phenolic compounds extracts of Northeast Portugal honey.Food ChemToxicol. ;46(12):3774-9.

Escuredo, O.; Silva, L.R.; Valentão, P.; Seijo, M.C.; Andrade, P.B. (2012); Assessing Rubus Honey Value: Pollen and Phenolic Compounds Content and Antibacterial Capacity. Food Chemistry, 130(3), 671-678.

Faciullino, A.L., Dhuique-Mayer, C., Luro, F., Casanova, J., Morillon, R., Ollitrault, P.,(2006). Carotenoid diversity in cultivated citrus is highly influenced by geneticfactors. J. Agric. Food Chem. $54,4397-4406$.

FurkanYardibi, M, Gumus, T. (2010). Some physico-chemical characteristics of honey produced from sunflower Plant ( helianthusAnnuus L), International journal of Food Sciences and Technology, 45 (4) , 707-712.

Ferreira, I.C.F.R., Aires, E., Barreira, J.C.M., Estevinho, L.M., (2009). Antioxidant activity of Portuguese honey samples: different contributions of the entire honey and phenolic extract. Food Chem. 114, 1438-1443.

Gupta, J.K., Kaushik, R. and Joshi, V.K. (1992). Influence of Different Treatments, Storage Temperature and Period on Some Physico-chemical Characteristics and Sensory Qualities of Indian Honey. J. Food Sci. Technol., 29: 84-87.

Graham, J.M,(1992), The hive and the Honeybee, Ed; Dadant\&Sons: Hamilton, II., . 
Gheldof N, Wang XH, Engeseth NJ (2002) Identification and quantification of antioxidant components of honey from various floral sources. J Agric Food Chem 50 (21): 5870-5877.

Gomes, S.; Dias, L.G.; Moreira, L.L.; Rodrigues, P.; Estevinho, L

(2010).Physicochemical, Microbiological, and Antimicrobial Properties of Commercial Honey from Portugal. Food and Chemical Toxicology , 48(2), 544-548.

Hartmann T., (2007). From waste products to ecochemicals : Fifty years research of plant secondary metabolism. Phyto chemisty ; 68: 2831 - 2846.

Iglesias, A., Fe_as, X., Rodrigues, S. et al. (2012). Comprehensive study of honey with protected denomination of origin and contribution to the enhancement of legal specifications. Molecules, 17, 856-8577.

James OO, Mesubi MA, Usman LA, Yeye SO, Ajanaku KO, et al. (2009) Physical characteristics of some honey samples from North-Central Nigeria. Int J PhySci 4: $464-470$.

Jeffrey AE, Echazarreta CM (1996) Medical uses of honey. RevistaBiomedica 7: 43 - 49.

Kaskoniene, V., Venskutonis, P.R., (2010). Floral Markers in Honey of Various Botanical and Geographical Origins: A Review. Comprehensive Reviews in Food Science and Food Safety 9, 620634 .

Khalil, M.I., Alam, N., Moniruzzaman, M., Sulaiman, S.A., Gan, S.H., (2011). Phenolic Acid Composition and Antioxidant Properties of Malaysian Honey. Journal of Food Science 76, C921C928.

Khalil,MISulaiman,S.A., Boukaraa,L(2010). Antioxidant properties of honey and it is preventing health disorders. The open Nutraceuticals Journal3 :5-16

Khalil MI, Moniruzzaman M, Boukraâ L, et al(2012). Physicochemical and antioxidant properties of algerian honey. Molecules. 17(9):11199-11215.

Kucuk, M., Kolaylı, S., Karaog־ lu, S_., Ulusoy, E., Baltacı, C., Candan, F., (2007). Biological activities and chemical composition of three honey of different types from Anatolia. Food Chem. 100, 526- 534 .

Louveaux J. (1968a). Composition, propriétés et technologie du miel. In: CHAUVIN R. Traité de biologie de l'abeille. Editions Masson et Cie, Paris, Tome 3, 277-324

Marchini, L.C., Reis, V.D.A. \&Moreti, A.C.C.C. (2006). Composicaofisico-quimicadeamostras de polencoletadoporabelhasafricanizadasApismellifera (Hymenoptera:Apidae) em Piracicaba, Estado de S ao Paulo. Ci^encia Rural, 36, 949-953.

Marcelo Enrique Conti, Jorge Stripeikis,Luigi Campanella,Domenico Cucina, Mabel Beatriz Tudino, (2007), Characterization of Italian honey (Marche Region) on the basis of their mineral content and some typical quality parameters, Chemistry Central Journal, 1:14.

Makhloufi C. (2001). Étude physico-chimique et palynologique de quelques miels de nord Algérien. Mémoire de magistèred'Agronomie, Université de Tiaret. $100 \mathrm{p}$

Miotto, D. (2011), Elucidation of the Components Involved in the Antioxidant Activity of Honey; Faculty of Biological Sciences, Brock University: St. Catharines, Ontario,

Martos, I., Ferreres, F., Toma' S,Barbera' n, F.A., (2000). Identification of flavonoid markers for the botanical origin of Eucalyptus honey. Journal of Agricultural and Food Chemistry 48, 1498-1502. 
Makloufi c. Kerkvliet D, ricciardDalboro G, choukri, Samar r(2010) characterization of AlgerainPoneys by palynological and physico-chimicalmethodes .Apidologie .41:509-521

Marceau, J. - Noreau, j. - Houle, e. 1994. Les HMF et la qualité du miel. Volume 15, numéros 2. Rapport de la Fédération des Apiculteurs du Québec, service de zootechnie, MAPAQ. , 4 p.

Meda, A.; Lamien, C.E.; Romito, M.; Millogo, J.; Nacoulma, O.G., (2005),Determination of the Total Phenolic, Flavonoid, and Proline Contents in Burkina Fasan Honey, As Well As Their Radical Scavenging Activity. Food Chemistry , 91(3), 571-577.

Medic Sanic M., Jasprica I., SmolcicBubalo A. and Mornar A., (2004). Optimization of chromatographic condition in thin layer chromatography of flavonoides and phenolics acids. CroaticaChemicaActa ; $3: 361-366$.

Molan, P.C., Betts, J.A., (2004). Clinical usage of honey as a wound dressing: an update. J. Wound Care 13, 353-356.

Moniruzzaman M, Khalil MI, Sulaiman SA, Gan SH. (2013), Physicochemical and antioxidant properties of Malaysian honey produced by Apiscerana, Apisdorsata and Apismellifera. BMC Complementary and Alternative Medicine.;13.

Orhan, F., Sekerel, B.E., Kocabas, C.N., Sackesen, C., Adaliog lu, G. \&Tuncer, A. (2003). Complementary and alternative medicine in children with asthma. Annals of Allergy. Asthma, and Immunology, 90, 611-615.

Overton S.V., Manura J.J. (1999). Flavor and aroma in natural bee honey. Scientific Instrument Services, Inc., Application Note 25.

Werner von Der Ohe,(1994), Unifloralhoney: chemical conversion and pollen reduction, Grana 33: 292-294, 1991

Papoff, C. M., Campus, R. L., Floris, I., \& Farris, G. A. (1995). Influence of temperature storage on the food quality of strawberry-tree honey (Arbutus unedo L.). IndustrieAlimentari, 34, 268-273.

Perdrix J .L. (2003). Critères de qualité du miel. Bulletin de liaison $\mathrm{N}^{\circ} 41$. Laboratoire d'analyse et d'écologie apicole, France.

Petrov V. (1974) Quantitative determination of aminoacids in someAustralianhoney, J. Apic. Res. 13, $61-66$

Piasenzotto L., Gracco L., Conte L. (2003)- SPME applied to honey quality control. Journal of the Science of Food and Agriculture. 83, 1037 - 1044.

Radovic B. S., Careri M., Mangia A., Musci M., Gerboles M., Anklam E. (2001)- Contribution of dynamic headspace GC-MS analysis of aroma compounds to authenticity testing of honey. Food Chemistry. 72, $511-520$.

Ramalhosa, E.E., Gomes, T.T., Pereira, A.P., Dias, T.T. \&Estevinho, L.M. (2011). Mead production tradition versus modernity. Advanced Food Nutritional Research, 63, 101-118.

Rodriguez-Amaya, D.B., (2001), A Guide to Carotenoid Analysis in Foods. ILSI Human Nutrition Institute. One Thomas Circle, NW, Washington DC, 20005-5802, 64. 
Running head: Biochemical and volatile honey profile

Sant'Ana, L.D.O., Souza, J.P.L.M., Salgueiro, F.B., Lorenzon, M.C.A., Castro, R.N., (2012). Characterization of monofloralhoney with multivariate analysis of their chemical profile and antioxidant activities. J. Food Sci. 71, 35-40.

Schweitzer P. (2004). Le monde des miellats. Revue l'abeille de France $n^{\circ} 908$. Laboratoired'analyse et d'EcologieApicole, $02 \mathrm{p}$

Soria A. C., Martinez-Castro I., Sanz J. (2002)- Analysis of volatile composition of honey by solid phase microextraction and gas chromatography-mass spectrometry. Journal of Separation Science. 26, $793-801$

Soto-Zamora, G., Yahia, E.M., Brecht, J.K., Garidea, A., (2005). Effects of postharvest hot air treatments on the quality and antioxidant levels in tomato fruit. IWT 38, 657-663.

Thibaut Istasse, Nicolas Jacquet, Thomas Berchem, Eric Haubruge, Bach Kim Nguyen, and AuroreRichel(2016), Extraction of Honey Polyphenols: Method Development and Evidence of Cis Isomerization, Anal Chem Insights. 2016; 11: 49-57.

R. Subramanian, H. UmeshHebbar\& N.K. Rastogi (2007) Processing of Honey: A Review, International Journal of Food Properties, 10:1, 127-143, DOI: 10.1080/10942910600981708.

Singh, N. and Bath, P.K. (1998). Relationship Between Heating and Hydroxymethylfurfural Formation in Different Honey Types. J. Food Sci. Technol., 35: 154-156.

Tosi, E.A., Ciappini, M., Re, E. and Lucero, H. (2002). Honey Thermal Treatment Effects on Hydoxymethylfurfural Content. Food Chem., 77: 71-74.

Thrasyvoulou A., Tananaki Ch., Manikis I., Karampournioti S., Tsellios D. (2002), The characteristic of Greek unifloralhoney. Proceedings of the 1st Hellenic Scientific Conference in ApicultureSericulture, $232-253$.

Tssigouri A, Passaloglou-Katrali M, Sabatakou O, ( 2004), Palynological characteristics of different aunifloralhoney from Greece, Grana, 43, 122-128.

Terrab A., Diez M.J., Heredia F.J. (2002) Characterisation of Moroccan unifloralhoney by their physicochemical characteristics, Food Chem. 79, 373-379.

Von der Ohe W., Dustmann J.H., von der Ohe K. (1991) ProlinalsKriterium der Reife des Honigs, Dtsch. Lebensm. Rundsch. 87, 383-386

Vargas, C., Sousa, S.M., Smania, E.F.A. \&Smania, A.J. (2007). Screening methods to determine antibacterial activity of natural products. Brazilian Journal of Microbiology, 38, 369-380.

Velioglu,Y. S., Mazza,G., Gao, L. and Oomah, B. D., (1998) - Antioxidant activity and total phenolics in selected fruits, vegetables, and grain products. Journal of Agricultural Food \& Chemistry, 46, 4113 4117

Viuda-Martos, M.; Ruiz-Navajas, Y.; Zaldivar-Cruz, J.M.; Kuri, V.; Fernández-López, J.; CarbonellBarrachina, Á.A.; Pérez-Álvarez, J(2010),. Aroma Profile and Physico - Chemical Properties of Artisanal Honey from Tabasco, Mexico. International Journal of Food Science and Technology, 45(6), $1111-1118$

Verzera A., Campisi S., Zappala M., Bonnaccorsi I. (2001)- SPME-GC-MS analysis of honey volatile components for the characterization of different floral origin. American Laboratory. 7, $18-21$. 
Running head: Biochemical and volatile honey profile

Vinh, T., Schwartz, G., \& Moll, M. (1981). Identification of 2-ethylhexanoic (2-ethyl-caproic) acid in beer. Journal of the American Society of Brewing Chemists, 39, 44-46.

Vorlova, L., Pridal, A.(2002): Invertase and diastase activity in honey of Czech provenience Actauniv. agric. et silvic. Mendel. Brun., , L, No. 5, pp.57-66

White, J.W., Doner, L.W., (1980). Honey Composition and Properties: Beekeeping in the United States. Agriculture Handbook , 335, 82-91.

Ulusoy, E.; Kolayli, S.; Sarikaya, A.O (2010). Antioxidant and Antimicrobial Activity of Different Floral Origin Honey from Turkiye. Journal of Food Biochemistry , 34(s1), 321-335. 